\title{
Is There a Value Premium Among Large Stocks?
}

\author{
Sandro C. Andrade Vidhi Chhaochharia \\ University of Miami University of Miami
}

September $2015^{*}$

\begin{abstract}
Fama and French (2012) find no significant global value premium among large stocks. Two simple departures from their methodology restore such premium: sorting stocks on price-toearnings rather than price-to-book ratios, and using global rather than regional value breakpoints. Using price-to-earnings computed from earnings estimates rather than historical earnings further sharpens the global value effect among large stocks. Not confined to small stocks, the value premium remains a highly economically significant phenomenon. Because valuation ratios are not interchangeable, researchers should consider looking beyond price-to-book when studying, or controlling for, the value effect.
\end{abstract}

Keywords: Value premium, global value investing, valuation ratios

\footnotetext{
${ }^{*}$ We thank Gennaro Bernile, Cam Harvey, Andrew Karolyi, Alok Kumar, Miguel Minutti-Meza, Stephen Penman, Will Prahl, and seminar participants at Miami for helpful comments and discussions. We are grateful to Ken French for posting a wealth of data on his website. All errors are ours. Please address correspondence to Sandro C. Andrade at sca@miami.edu.
} 


\section{Introduction}

Value investing consists of overweighting securities with low valuation ratios and underweighting securities with high valuation ratios. The "value premium", the tendency of stocks with low valuation ratios to outperform stocks with high valuation ratios, is one of the most important topics in academic Finance. Moreover, a large and growing fraction of the asset management industry is organized around the premise that the value premium is a robust feature of stock markets around the world.

Recent research, however, indicates it is hard to harvest any value premium among large stocks globally. Fama and French (2012) pool large stocks across the world and find that low price-to-book (P/B) stocks do not significantly outperform high $\mathrm{P} / \mathrm{B}$ stocks. By definition, large stocks in Fama and French (2012) comprise 90\% of global market capitalization. If in fact the value premium is confined to the remainder $10 \%$ of small and typically illiquid stocks, then its status at the center of Finance would seem unwarranted. ${ }^{1}$

This paper shows there is an economically large and statistically significant global value premium among large stocks. Two simple departures from Fama and French's (2012) methodology restore such premium. ${ }^{2}$ First, and more importantly, we sort stocks using price-to-earnings (P/E) rather than P/B ratios. Second, while Fama and French (2012) force region neutrality by defining separate sets of value breakpoints for each of four world regions, we adopt a fully global approach and thus use a single set of global value breakpoints.

From July 1990 to June 2013, our value-weighted long-short portfolio HML B $_{\mathrm{B}}$ (top 30\% minus bottom 30\%) earns 64 basis points per month on average ( $\mathrm{t}$-stat=2.61), compared to

\footnotetext{
${ }^{1}$ Fama and French (2012) study global stock returns, and the global value premium. Other papers document the inability of price-to-book sorts to detect a value premium among large stocks within the United States, for example Loughran (1997) and Israel and Moskowitz (2013). The latter state on p. 276: "The value premium, meanwhile, is largely concentrated only among small stocks and is insignificant among the largest two quintiles of stocks."

${ }^{2}$ Like Fama and French (2012), we (i) study developed market stock returns after July 1990; (ii) label a stock "large" if it is within the largest stocks cumulatively comprising $90 \%$ of total market capitalization; (iii) perform annual rebalances at the end of June of each year; (iv) focus on Top 30\% minus Bottom 30\% long-short portfolios; (v) do not discard financial firms.
} 
Fama and French's 17 basis points (t-stat=1.09). Our $\mathrm{HML}_{\mathrm{B}}$ has a World CAPM alpha of 77 basis points per month ( $\mathrm{t}$-stat=3.34), compared to 17 basis per month of Fama and French's HML $_{B}$ (t-stat=0.97). That is, in contrast to Fama and French $(2012)$, our portfolio sort results uncover a large and statistically significant global value premium over the previous three decades. ${ }^{3}$

Regressions of individual stock returns confirm our portfolio sort results. In univariate Fama-McBeth regressions, the coefficient on $(\log ) \mathrm{B} / \mathrm{P}$ (inverse of $\mathrm{P} / \mathrm{B}$ ratio) is positive but statistically insignificant, while the coefficient on $\mathrm{E} / \mathrm{P}$ (inverse of $\mathrm{P} / \mathrm{E}$ ratio) is statistically significant. When both $\mathrm{B} / \mathrm{P}$ and $\mathrm{E} / \mathrm{P}$ are included as regressors, the coefficient on $\mathrm{E} / \mathrm{P}$ remains statistically significant, while the coefficient on $\mathrm{B} / \mathrm{P}$ remains insignificant and becomes even closer to zero. That is, among large stocks, valuation ratios are not interchangeable. There is a global value effect among large stocks, but one needs to use $\mathrm{P} / \mathrm{E}$ rather than $\mathrm{P} / \mathrm{B}$ ratios to identify it.

An additional departure from Fama and French's (2012) methodology further sharpens the global value effect among large stocks. Rather than using backward looking earnings from financial statements, we use forward looking earnings from analysts' estimates. In FamaMcBeth regressions of individual stock returns, $\mathrm{P} / \mathrm{E}$ ratio computed from earnings estimates, which we label $\mathrm{P} / \mathrm{E}[\mathrm{E}]$, subsumes the information on $\mathrm{P} / \mathrm{E}$ ratio computed from historical earnings. Therefore, it is possible to use earnings estimates to more accurately classify a stock in the value-growth/glamour spectrum, and to form value-investing portfolios with higher prospective returns. ${ }^{4}$ For example, the zero-cost portfolio that buys the cheapest

\footnotetext{
${ }^{3}$ We replicate Fama and French's (2012) procedures using our data, which come from different sources. Results are nearly identical. For example, in our data, and for the same July 1990 to June 2013 time period, Fama and French's global $\mathrm{HML}_{\mathrm{B}}$ earns 17 bps per month on average (t-stat=1.09), exactly the same as using $\mathrm{HML}_{\mathrm{B}}$ from French's website. The correlation between the two global $\mathrm{HML}_{\mathrm{B}}$ time series is 0.953 .

${ }^{4}$ We do not claim that analyst opinions are unbiased. In fact, Michaely and Womack (1999) provide strong evidence that analysts buy/sell recommendatios are not unbiased. Whether or not the disadvantage of any bias outweight the advantage of using forward-looking earnings estimates vs. backward looking realized earnings is a matter to be resolved empirically. Moreover, we note: (i) Recent research by Kecskes, Michaely, and Womack (2013) show that analysts buy/sell recommendations that are backed by their own earnings estimates, which they label "earnings-based" recommendations, are more accurate and valuable to investors, despite potential biases. (ii) In the case of large stocks, the focus of this paper, incentive-based biases arising from underwriting relationships are likely
} 
decile and shorts the priciest decile according to $\mathrm{P} / \mathrm{E}[\mathrm{E}]$ earns on average 104 bps per month (t-stat $=2.54)$, considerably more than the corresponding 71 bps per month on average using $\mathrm{P} / \mathrm{E}$ from historical earnings $(\mathrm{t}-\mathrm{stat}=3.03) .^{5}$

Finally, we provide an additional example of how the choice of valuation ratio matters. We analyse the "profitability premium" in global stock returns. The profitability (ROE) premium in US stocks was first documented by Haugen and Baker (1996), and also studied by Fama and French (2006), Hou, Xue, and Zhang (2012), and Wang and Yu (2013). Like in the US only case, high-ROE (return on equity) stocks tend to earn higher returns than low-ROE stocks in our global sample. This global ROE effect is robust to controlling for the value effect using $\mathrm{P} / \mathrm{B}$ ratios. However, it is not robust to controlling for value using $\mathrm{P} / \mathrm{E}$ ratios. In Fama-MacBeth regressions, P/E ratios subsume information about future returns contained in ROE. In our sample of large global stocks, ROE does forecast returns in the cross-section, but only so because it inherits the predictive power of $\mathrm{P} / \mathrm{E}$, to which ROE is linked by an accounting identity. ${ }^{6}$

Our results have two implications. First, the value premium is not confined to small and typically illiquid stocks amounting to a modest fraction of market capitalization. Therefore, contrary to what global results in Fama and French (2012) and US only results in Israel and Moskowitz (2013) may suggest, the value premium remains a highly economically significant phenomenon.

Second, and in line with recent research, we demonstrate that valuation ratios are not interchangeable. There is no global value effect using price-to-book ratios, but there is a strong effect using price-to-earnings ratios. The global value effect is even stronger when

to be less relevant in distorting analysts' aggregate opinion. This is because large stocks tend to be followed by many analysts (12.6 on average in our sample), which dilutes the effect of any single analyst on average earnings estimates.

${ }^{5}$ The corresponding top $10 \%$ minus bottom $10 \%$ zero-cost portfolio based on Fama and French's (2012) methodology earns 33 bps per month (t-stat=1.36).

${ }^{6}$ The inexistence of an independent ROE-effect applies to our sample of large global stocks, and may not generalize to other samples. We see our analysis of the global ROE effect as a cautionary example of the consequences of the non-interchangeability of valuation ratios. We make no claims regarding the transferability of our results to other samples. 
$\mathrm{P} / \mathrm{E}$ ratios are computed from earnings estimates rather than historical earnings. Moreover, there is an independent global ROE-effect using $\mathrm{P} / \mathrm{B}$ to control for the value effect, but such an effect disappears when $\mathrm{P} / \mathrm{E}$ is used to control for value. Researchers studying the value premium, or wishing to control for the value premium, should consider looking beyond price-to-book ratios. ${ }^{7}$

The paper proceeds as follows. Section 2 has a brief review of the literature. Section 3 describes our data sources and sample construction. Section 4 has our main results. While our main results pool stocks across the world, Section 5 reports results within each of four world regions. Section 6 discusses controlling for value in the context of the global ROE effect. Section 7 concludes the paper.

\section{Related literature}

Value investing has a long history in Finance, dating at least to Graham and Dodd (1940). Basu (1977) is the first comprehensive empirical study of the value premium. He shows that low $\mathrm{P} / \mathrm{E}$ stocks tend to earn higher subsequent returns than high $\mathrm{P} / \mathrm{E}$ stocks. Later, Rosenberg, Reid, and Lanstein (1985) find that stocks with low P/B also tend to outperform stocks with high $\mathrm{P} / \mathrm{B}$.

It is hard to overstate the importance of Eugene Fama and Kenneth French's value premium research in 1990s. In a seminal paper, Fama and French (1992) clearly demonstrate the value premium is both robust and at odds with the Capital Asset Pricing Model. They also show that, in their sample of all US stocks in the 1962-1990 period, $\mathrm{P} / \mathrm{B}$ ratios subsume

\footnotetext{
${ }^{7}$ There could be multiple reasons why $\mathrm{P} / \mathrm{B}$ ratios fail to summarize information about value. Most notably, there are measurement issues. The rise of intangible capital as a factor of production over recent decades (Lev 2001, Eisfeldt and Papanikolau 2013) substantially weakens the validity of book value of equity as a measure of capital, broadly defined. Moreover, book value of equity accumulates long-term historical profits and is affected by the history of mergers and acquisitions (Custodio 2014). For older firms, a large book value of equity may simply reflect a combination of profits generated a long time ago and recent expensive acquisitions. These, compared to current earnings entering P/E calculations, provide little insight into a firm's future earnings. Penman et al. (2014) presents an accounting framework to explain why $\mathrm{P} / \mathrm{B}$ must be complemented by $\mathrm{P} / \mathrm{E}$ in a characteristic-based asset pricing model.
} 
the information about future returns contained in $\mathrm{P} / \mathrm{E}$ ratios. Because of this finding, subsequent research on the value premium would focus primarily on $\mathrm{P} / \mathrm{B}$ ratios.

Later research calls into question the economic significance of the value effect. Loughran (1997) shows that $\mathrm{P} / \mathrm{B}$ sorts cannot identify a value premium among large US stocks. Israel and Moskowitz (2013) study $\mathrm{P} / \mathrm{E}$ and price-to-cashflow $(\mathrm{P} / \mathrm{C})$ in addition to $\mathrm{P} / \mathrm{B}$, and still conclude (p. 295) that the returns to value are insignificant for the largest stocks. This matters because large stocks comprise most of stock market capitalization, thus the value premium would be confined to a modest corner of the stock market. Ali, Hwang, and Trombley (2003), Nagel (2005), and Phallipou (2008) find the P/B effect is concentrated among stocks that are costly to trade and hard to short-sell, which suggests that harvesting the value premium would be difficult. ${ }^{8}$

Loughran and Wellman (2011) show that the choice of valuation ratio matters. They document a value effect in US stocks using Enterprise Value (EV) over EBITDA, an increasingly popular valuation ratio. Importantly, they show that $\mathrm{P} / \mathrm{B}$ does not subsume information about future returns contained in EV/EBITDA. Moreover, they find a EV/EBITDA value effect among all quintiles of US stocks in the 1963-2009 period, including an effect within the largest size quintile. ${ }^{9}$

Starting with Fama and French (1998), a few papers study the global value premium, pooling stocks from different countries. Fama and French (1998) and Hou, Karolyi, and Kho (2011) find a significant global value premium based on either $\mathrm{P} / \mathrm{B}, \mathrm{P} / \mathrm{E}$, or $\mathrm{P} / \mathrm{C}$. Importantly, the multivariate Fama-McBeth regressions in Hou, Karolyi, and Kho (2011) show that the coefficients on all valuation ratios remain statistically significant. Therefore,

\footnotetext{
${ }^{8}$ Similarly, Houge and Loughran (2006) show there is no evidence of evidence of a significant value premium in the returns of style indexes, large-capitalizations firms, or equity mutual funds, and as such conclude (p.17) that the value premium is beyond the reach of investors.

${ }^{9}$ Loughran and Wellman (2011) show that, in the top size quintile, the average return spread between top $20 \%$ and bottom $20 \%$ stocks sorted on EV/EBITDA is 28 bps per month over the 1963-2009 period, with a CAPM alpha of 34 bps per month (t-stat=1.84). Using 1963-2009 data from Ken French's website, we find the average return spread (top $20 \%$ minus bottom 20\%) among top quintile stocks and using P/B is 19 bps per month, less than the 28 bps per month using EV/EBITDA.
} 
differently from US results in Fama and French (1992), and similar to Loughran and Wellman (2011), no single valuation ratio subsume information about future returns contained in the collection of valuation ratios. ${ }^{10}$

While neither Fama and French (1998) nor Hou, Karolyi, and Kho (2011) distinguish between small stocks and large stocks, Fama and French (2012) study the global value premium in large and small stocks separately. ${ }^{11}$ They focus on $\mathrm{P} / \mathrm{B}$ sorts, not considering other valuation ratios. Fama and French's (2012) global value premium results mirror US results in the rest of the literature. They find an economically large and statistically significant global value premium among small stocks, but a small and insignificant value premium among large stocks. $^{12}$

\section{Data and sample construction}

We study stock returns from 23 developed markets, listed in Table 1. Our sample construction begins with Datastream. From Datastream we obtain end of month return index and market capitalization for all stocks, active and inactive, from 1990 to 2013, both in US dollars and in local currency. Our calculations use US dollar denominated data, but local currency data are used to flag stale observations. Specifically, we delete observations when there are three consecutive months of identical prices, return index, and market capitaliza-

\footnotetext{
${ }^{10} \mathrm{Hou}$, Karolyi, and Kho (2011) also find that the $\mathrm{P} / \mathrm{C}$ valuation ratio is the best for creating factor mimicking portfolios used in asset pricing tests. This is because (i) $\mathrm{P} / \mathrm{C}$-based factors generate smaller pricing errors in average than factors constructed from alternative valuation ratios; (ii) unlike other valuation ratios, what matters for average stock returns is risk-loadings on the $\mathrm{P} / \mathrm{C}$ factor as opposed to $\mathrm{P} / \mathrm{C}$ as a characteristic.

${ }^{11}$ As Fama and French $(2008 \mathrm{a}, 2012)$ discuss, univariate portfolio sorts on characteristics tend to be dominated by small stocks. In addition to being more plentiful than large stocks, small stocks tend to have more disperse characteristics than large stocks. Thus, long-short portfolios based on extreme deciles/quintiles, even when valueweighted, tend to oversample small stocks. In other words, suppose that small stocks comprise $80 \%$ of all stocks adding to $10 \%$ of market value. The extreme quintile portfolios based on univariate sorts will tend to have more than $80 \%$ of small stocks and these will tend to add to more than $10 \%$ of the market cap of extreme quintiles portfolios.

${ }^{12}$ Asness and Frazzini (2013) also study global value investing strategies. Like Fama and French (2012), they use $\mathrm{P} / \mathrm{B}$ sorts. However, they compute $\mathrm{P} / \mathrm{B}$ ratios using more timely prices, and use country-level rather than regional value breakpoints. Asness and Frazzini (2013) show their long-short value portfolios actually earn lower average returns than standard Fama-French sorts because they have an "anti-momentum" tilt by construction. Nonetheless, their are better suited for combining with momentum strategies because their have a much more negative correlation with momentum. Asness and Frazzini (2013) do not report large and small stock results separately.
} 
tion in local currency. We then delete stocks identified as cross-listings. At this point, there are on average 16,081 firms per year in the sample, both large and non-large. ${ }^{13}$

This paper focuses on large stocks. Following Fama and French (2013), we label a stock "large" if it is among the largest stocks cumulatively comprising $90 \%$ of total market capitalization. At the end of June each year, we pool stocks across all developed markets, and rank them by market capitalization to define market cap breakpoints for the subsequent 12 months. Stocks below the minimum market capitalization are deleted. At this point, this leaves us with on average 2,947 large stocks per year in the sample.

From Worldscope (via Thomson One Banker) we obtain annual valuation ratios for our sample of large stocks. The Worldscope datatypes for P/E and P/B ratios are WC09104 and WC09304, respectively. These items are calculated on a calendar year-end basis for US firms and on a fiscal year-end basis for non-US firms, and are matched to subsequent year end-of-June Datastream data. We delete stocks for which we do not have valuation ratios. Our final sample has 2,752 large stocks per year on average, representing on average $94.4 \%$ of the universe of large stocks, and $85 \%(94.4 \% \times 90 \%)$ of total market cap. Figure 1 plots the minimum marlet cap and the number of stocks in our final sample as of June of each year.

\section{FIGURE 1}

Table 1 has summary statistics for our sample stocks. The table shows the United States is the country with largest number of stocks in the sample, followed by Japan, and the United Kingdom. North America is the region with the largest number of stocks and largest market capitalization, followed by Europe, then Japan, then Asia-Pacific ex Japan. Median $\mathrm{E} / \mathrm{P}$ ratios (inverse of $\mathrm{P} / \mathrm{E}$ ratios) range from 0.032 for Japan to 0.084 for Greece. Median $\mathrm{B} / \mathrm{P}$ ratios (inverse of $\mathrm{P} / \mathrm{B}$ ratios) range from 0.40 for the United States to 0.76 for

\footnotetext{
${ }^{13}$ Figure A-1 in the Appendix compares our data coverage to Fama and French's (2012) and Asness and Frazzini's (2013), all using different data sources.
} 
Finland. Pooling stocks globally, the median E/P and B/P ratios globally are 0.047 and 0.46, respectively. The annual (subsequent) stock return in excess of one-month US T-bills ranges from -0.003 in Japan to 0.127 in Finland.

\section{TABLE 1}

For the (large) subsample of stocks with analyst coverage, we also use monthly I/B/E/S data to compute $\mathrm{P} / \mathrm{E}$ ratios using analyst estimates of earnings per share (EPS). We label these P/E[E]. Both EPS estimates and prices are from I/B/E/S. We use I/B/E/S's Summary Statistics files, which calculates average EPS estimates as of the third Thursday of each month (statpers variable). Prices, obtained from I/B/E/S Actuals, Pricing, and Ancillary files, are typically as of the day before the third Thursday of each month. ${ }^{14}$ To compute $\mathrm{P} / \mathrm{E}[\mathrm{E}]$ ratios from $\mathrm{I} / \mathrm{B} / \mathrm{E} / \mathrm{S}$, we use the average of the EPS estimates for fiscal years $t, t+1$, and $t+2$ (i.e., the average of these three averages) if all three averages exist and are nonnegative. ${ }^{15}$ If not, we use whichever non-negative averages are available. ${ }^{16}$ These $\mathrm{P} / \mathrm{E}[\mathrm{E}]$ ratios, as of the third Thursday of month, are matched to end of month Datastream data, Therefore, analysts estimates are lagged by at least 10 days relative to subsequent stock returns.

Table 1 also has summary statistics for our subsample of stocks with analyst coverage. On average, we can compute a $\mathrm{P} / \mathrm{E}[\mathrm{E}]$ ratio for 2,506 of the 2,752 large stocks in our sample, corresponding to $93.6 \%$ of the market capitalization of our final large stock sample. Therefore, not much is lost in terms of sample coverage by requiring analyst coverage. In

\footnotetext{
${ }^{14}$ If the I/B/E/S price is missing, or is a price as of more than one day after the third Thursday of the month (statpers), we use the price as of the previous month's statpers. This happens to less than $5 \%$ of the cases in the entire I/B/E/S dataset from 1990-2013.

${ }^{15}$ We average earnings over three fiscal years to smooth out the effect of transitory earnings shocks. Easton, Harris, and Ohlson (1992) show that stock returns and earnings display a much stronger cross-sectional, contemporaneous relation when earnings and returns are aggregated over several years.

${ }^{16}$ If all existing earnings estimates are negative, $\mathrm{P} / \mathrm{E}[\mathrm{E}]$ is set to infinity, or equivalenty, the earnings yield $\mathrm{E}[\mathrm{E}] / \mathrm{P}$ is set to zero. On average at each point in time, this affects only 37 out of the 2,506 stocks with analyst coverage in our sample.
} 
general, the distribution of stocks per country mirrors that of the full global sample, with the exception that there are relatively less Japanese stocks with analyst coverage. Conditioned on having analyst coverage, on average our sample stocks are followed by 12.6 analysts. ${ }^{17}$ The average number of analysts per stock ranges from 2 in Greece to 18.4 in Singapore.

Table 1 shows that, for all countries the median earnings yield (inverse of $\mathrm{P} / \mathrm{E}$ ratio) using earnings estimates is above the median earnings yield using historical earnings. This could be because analysts tend to be optimistic in their estimates. Or it could because analysts forecast a different definition of earnings. Bradshaw and Sloan (2002) show that analysts explicitly exclude a variety of expenses required under "generally accepted accounting principles" (GAAP). ${ }^{18}$ Not shown in table, the cross-country dispersion of median earnings yields using earnings estimates is similar to that using historical earnings.

\section{Global results}

\subsection{Portfolio sorts}

At the end of June each year, we pool stocks globally and sort them by E/P (inverse of P/E). We allocate stocks into three groups: low (bottom 30\%), medium (mid 40\%), and high (top 30\%). We form value-weighted portfolios of these three groups. Portfolios are held for one year, and then rebalanced at the end of June of the subsequent year. We compute dollar-denominated returns in excess of the 1-month T-bill. If there is a value premium among large stocks, the "cheap" portfolio with high E/P should have higher average excess returns then the "expensive" portfolio with low E/P.

\section{TABLE 2}

\footnotetext{
${ }^{17}$ We define the number of analysts following a stock as the maximum number of EPS estimates for fiscal years $t$, $\mathrm{t}+1$, and $\mathrm{t}+2$.

${ }^{18}$ Interestingly, Bradshaw and Sloan (2002) show that stock returns are more strongly associated with earnings forecast errors using analysts' modified version of earnings than with earnings forecast errors using GAAP earnings. They conclude that the market focuses on the modified version of earnings used by analysts rather than GAAP earnings. 
Table 2, Panel A shows there is a value premium among large stocks. On average, the Low E/P portfolio earns 4 basis points per month in excess of 1-month T-bill, while the High E/P portfolio earns 68 basis points per month. This 64 basis points average difference is more than two standard deviations from zero $(\mathrm{t}-\mathrm{stat}=2.61)$.

We repeat the same sorting procedure using Fama and French's (2012) methodology. First, we use $\mathrm{B} / \mathrm{P}$ ratios (inverse of $\mathrm{P} / \mathrm{B}$ ) instead of using $\mathrm{E} / \mathrm{P}$ ratios. Second, instead of pooling stocks globally and then sorting them into three groups, we first separate stocks into four world regions (North America, Europe, Asia-Pacific ex Japan, and Japan), and only then sort stocks into three groups, within each region. The three groups across the four regions are then aggregated globally, and value-weighted portfolios are formed. That is, we use regional breakpoints for the (inverse) valuation ratio, instead of global breakpoints. ${ }^{19}$

Table 2, Panel A shows it is not possible to detect a value premium among large stocks using Fama and French's (2012) methodology. While the low B/P portfolio does earn lower excess returns than the high $\mathrm{B} / \mathrm{P}$ group, the 17 basis points per month difference is economically small and statistically insignificant $(\mathrm{t}$-stat $=1.09) .{ }^{20}$

Table 2, Panel B shows that both our departures from Fama and French's (2012) methodology contribute to finding a global value premium among large stocks. First we sort stocks by $\mathrm{E} / \mathrm{P}$ but using regional rather than global breakpoints. In this case, the return spread between Top 30\% and Bottom 30\% value-weighted portfolios is on average 37 basis points per month. The average difference is still more than two standard deviations from zero ( $t$ -

\footnotetext{
${ }^{19}$ Fama and French (2012) use regional rather than global value breakpoints in order to "mitigate any effects of differences in accounting rules across the four regions". However, these accounting rule differences have presumably become less important over time after decades of global accounting convergence efforts (FASB, 2012). In the end, whether a potential increase in precision granted by potentially more comparable valuation ratios compensates for the additional restriction placed on the global strategy (i.e., neutrality within each region) is a question to be resolved empirically.

${ }^{20}$ We obtain these results using our data. To check our data and code, we donwload the corresponding Fama and French (2012) data from Ken French's website. Using their data, we calculate that the difference between Top $30 \%$ $\mathrm{B} / \mathrm{P}$ minus Bottom 30\% B/P value-weighted portfolios is 17 basis points per month on average from July 1990 to June 2013 (t-stat=1.09), exactly the same we obtain. The correlation between the two global HML $\mathrm{H}_{\mathrm{B}}$ time series is 0.953 .
} 
stat $=2.38$ ), and more than twice as large as the average difference using Fama and French's (2012) methodology. However, even though it is economically large and statistically significant, the 37 bps average return spread using regional breakpoints is substantially smaller than the 64 bps using global breakpoints. Therefore, using global rather than regional breakpoints matters.

Table 2, Panel $\mathrm{B}$ also shows that using a different valuation ratio matters more than using global rather than regional breakpoints. This is because we cannot detect a value premium among large stocks using global breakpoints but sorting on $\mathrm{B} / \mathrm{P}$. In this case, the return spread between Top 30\% and Bottom 30\% value-weighted portfolios is on average 15 basis points per month $(\mathrm{t}$-stat $=0.86)$. This is about the same as sorting on $\mathrm{B} / \mathrm{P}$ and using regional breakpoints as Fama and French (2012).

Table 2, Panel $\mathrm{C}$ shows that the higher excess returns of our long-short $\mathrm{HML}_{\mathrm{B}}$ portfolio (High E/P minus Low E/P among big stocks) cannot be explained by the World CAPM. We report the CAPM alpha and beta in time series regressions of $\mathrm{HML}_{\mathrm{B}}$ onto the excess returns of the global market portfolio. The table shows that the CAPM alpha of $\mathrm{HML}_{\mathrm{B}}$ using $\mathrm{P} / \mathrm{E}$ with global breakpoints is 77 basis points per month $(\mathrm{t}$-stat $=3.34$ ), even larger than the corresponding average excess return of 64 basis points per month. This is because our $\mathrm{HML}_{\mathrm{B}}$ has a small but highly statistically significant negative exposure to the global market portfolio. The market beta is -0.33 ( $\mathrm{t}$-stat=-4.62), so that $\mathrm{HML}_{\mathrm{B}}$ adds extra value by hedging against movements in global stock markets. In contrast, using $\mathrm{P} / \mathrm{B}$ and regional breakpoints as in Fama and French (2012) leads to zero exposure to the global market. That is, accounting for market betas actually increases the value premium detected by our departures from Fama and French's methodology.

Results in Table 2, Panel C show that our $\mathrm{HML}_{\mathrm{B}}$ portfolio is not just a levered up version of Fama and French's (2012) HML $_{\mathrm{B}}$. The correlation between our HML $\mathrm{H}_{\mathrm{B}}$ (P/E with global breakpoints) and Fama and French's $\mathrm{HML}_{\mathrm{B}}(\mathrm{P} / \mathrm{B}$ with regional breakpoints) is equal to 
0.51, that is, positive but moderate. Therefore, the beta of our $\mathrm{HML}_{\mathrm{B}}$ relative to Fama and French's $\mathrm{HML}_{\mathrm{B}}$ is $0.80\left(\beta=0.51 \times \frac{0.041}{0.026}\right)$, so our $\mathrm{HML}_{\mathrm{B}}$ does not merely lever up Fama and French's s HML $L_{B}$. The corresponding alpha of our HML $L_{B}$ relative to Fama and French's is therefore 50 basis points per month $(\alpha=64-0.80 \times 17)$, with robust t-statistics equal to 2.38 .

\subsection{Fama-McBeth regressions}

Table 3 contains results of Fama-McBeth regressions of individual stock monthly returns on stock characteristics. We follow Fama and French (1992) in the definition of variables. In particular, E/P Dummy is equal to 1 when a stock has negative earnings, in which case its earnings yield (inverse of $\mathrm{P} / \mathrm{E}$ ratio) is set to 0 . This is why the dependent variable corresponding to the earnings yield is denoted by $E(+) / P$. Differently from Fama and French (1992), and following Loughran and Wellman (2011), we add the prior return from month t-2 to month t-12 to capture the momentum effect. To prevent outliers from unduly influencing results, dependent variables are winsorized at the $1 \%$ level at both tails using the entire sample. ${ }^{21}$ Panel A provides summary statistics of the (already winsorized) variables. The pairwise correlations between valuation ratio variables, not displayed in the table, are respectively $0.49(E(+) / P$ and $E[E] / P), 0.26(E(+) / P$ and $\ln (B / P))$, and $0.29(E[E] / P$ and $\ln (B / P))$. Regression results are in Panel B.

\section{TABLE 3}

The first two columns of Table 3, Panel B confirm our portfolio sort results. There is a value effect among large stocks, but one needs to use $\mathrm{P} / \mathrm{E}$ ratios to identify it. In univariate

\footnotetext{
${ }^{21}$ Differently from Fama and French (2012), we do not discard stocks with negative book value of equity. We cannot calculate $\log (\mathrm{B} / \mathrm{P})$ for these variables. To deal with them, we effectively winsorize the $\mathrm{B} / \mathrm{P}$ variable at the $1.4 \%$ at the lower tail. Our conclusions are robust to discarding negative B/P stocks.
} 
regressions, the coefficient on $E(+) / P$ is positive and statistically significant at the $1 \%$ level, while the coefficient on $\ln (B / P)$ is positive but statistically insignificant. The coefficient on the $E / P$ Dummy is indistinguishable from zero. When both $E(+) / P$ and $\ln (B / P)$ enter the regression in column $(3)$, the coefficient on $E(+) / P$ remains positive and statistically significant, whereas the coefficient on $\ln (B / P)$ changes sign and becomes even closer to zero in absolute value, while remaining insignificant.

Note that results in Columns (1) and (2) differ from those on Fama and French's (1992) seminal paper. In that paper, information in $\mathrm{P} / \mathrm{B}$ ratios subsume information in other valuation ratios. In multivariate regressions of stock returns on $\mathrm{P} / \mathrm{B}$ and other valuation ratios, the coefficient on $\mathrm{P} / \mathrm{B}$ is statistically significant while the coefficients on the other valuation ratios are not. Grounded on these findings, Fama and French's subsequent research on the value premium would focus on P/B ratios (e.g., Fama and French 1993, 2006, 2008a, 2008b, 2012, 2014). The literature followed: virtually all empirical stock return studies since the mid 90's use Fama and French's P/B portfolio sorts to capture the value premium. In contrast, Table 3 results show that, at least among large global stocks, $\mathrm{P} / \mathrm{E}$ ratios are better suited to capture the value premium than $\mathrm{P} / \mathrm{B}$ ratios.

Columns (4) and (5) show there is a value effect after controlling for size and momentum effects. We find that the value effect we identify using $\mathrm{P} / \mathrm{E}$ ratios is robust to adding $\ln ($ Market Cap) and $\ln (1+$ Prior Return $)$ : the coefficient on $E(+) / P$ remains positive and statistically significant in both cases. We note that, consistent with the existence of a momentum effect among large global stocks, the coefficient on $\ln (1+$ Prior Return $)$ is positive, but it is statistically insignificant. In that sense, among large stocks globally, the value effect is stronger than the momentum effect. ${ }^{22}$

\footnotetext{
${ }^{22}$ This is in contrast to Asness et al. (2014), who state that "Momentum, unlike value, is far more robust among large versus small stocks". Differently from us, Asness et al. (2014) restrict their analysis to US stocks and P/B sorts. Column 5 of Table 5 shows that expanding the universe from the US to global stocks and enlarging the set of valuation ratios to include $\mathrm{P} / \mathrm{E}$ ratios reverses their conclusion.
} 
Columns (6) and (7) show that one can also identify a value effect using $\mathrm{P} / \mathrm{E}$ ratios calculated using earnings estimates. As explained in Section 3, these earnings estimates are calculated on a monthly basis, with at least 10 days lag relative to subsequent stock returns. Column (6) shows a value effect using $E[E] / P$, the inverse $\mathrm{P} / \mathrm{E}$ ratio calculated from earnings estimates. Column (7) shows the value effect using $E[E] / P$ after adding $\ln (B / P)$ and controlling for size and momentum. Note that the coefficient on $\ln (B / P)$ is negative, small, and statistically insignificant.

Column (8) show that using earnings estimates to compute $\mathrm{P} / \mathrm{E}$ ratios, an additional departure from Fama and French's (2012) methodology, actually sharpens the value effect among large stocks. When both $E[E] / P$ and $E(+) / P$ enter the regression, $E[E] / P$ remains positive and statistically significant, while $E(+) / P$ is no longer statistically significant. That is, $\mathrm{P} / \mathrm{E}$ ratios calculated from earnings estimates subsume the information on $\mathrm{P} / \mathrm{E}$ ratios calculated from historical earnings. Therefore, it is possible to use earnings estimates to more accurately classify a stock in the value-growth/glamour spectrum, and to form valueinvesting portfolios with higher expected returns.

\subsection{Decile sorts}

This subsection has portfolios results using a finer partition of the stock universe, as stocks are sorted into deciles instead of 30/40/30\%. This finer partition allows us to better gauge how monotonic the relation between returns and valuation ratios are. As in Table 2, we first compare sorting stocks on $\mathrm{P} / \mathrm{E}$ ratios with global breakpoints to sorting stocks on $\mathrm{P} / \mathrm{B}$ ratios with regional breakpoints. The resulting decile portfolios are value-weighted and rebalanced annually, at the end of June each year. Given our Table 3 results demonstrating the usefulness of earnings estimates, we also sort stocks on $\mathrm{P} / \mathrm{E}[\mathrm{E}]$ using global breakpoints. ${ }^{23}$ These $\mathrm{P} / \mathrm{E}[\mathrm{E}]$ decile portfolios are monthly rebalanced.

\footnotetext{
${ }^{23}$ We cannot use $\mathrm{P} / \mathrm{E}[\mathrm{E}]$, which is based on earnings estimates, to sort stocks without analyst coverage (on average, 246 out of our universe of 2,752 stocks per year). Rather than simply discarding those, we assign them to portfolios based on $\mathrm{P} / \mathrm{E}$. That is, we first sort stocks with analyst coverage by $\mathrm{P} / \mathrm{E}[\mathrm{E}]$ and assign them to one of the decile portfolios. Then we sort (all) stocks by $\mathrm{P} / \mathrm{E}$, and assign each stock without analyst coverage to one of the ten decile portfolios based on this sort. 
Table 4 has excess returns and World CAPM alphas of value-weighted decile portfolios. We also report the differences between Deciles 10 and 1, as well as the differences between the averages of Deciles 10 and 9 and the average of Deciles 1 and 2, and the differences between the averages of Deciles 10, 9, and 8 and the averages of Deciles 1,2 and 3. Figure 2 has a visual representation of results in Table 4. We plot the World CAPM alpha across Decile portfolios. The left panel compares $\mathrm{P} / \mathrm{E}$ and $\mathrm{P} / \mathrm{B}$ sorts, while the right panel compares $\mathrm{P} / \mathrm{E}[\mathrm{E}]$ and $\mathrm{P} / \mathrm{B}$ sorts.

\section{TABLE 4}

\section{FIGURE 2}

Table 4 confirms that sorting on $\mathrm{P} / \mathrm{E}$ ratios and using global breakpoints uncovers a global value effect among large stocks, while sorting on $\mathrm{P} / \mathrm{B}$ ratios and using regional breakpoints does not. The differences between excess returns of $\mathrm{P} / \mathrm{B}$-sorted portfolios range from 20 to 33 bps per month, and are not statistically significant, not even when comparing Decile 10 to Decile 1. The CAPM alphas are not statistically significant either. In contrast, the differences between excess returns of $\mathrm{P} / \mathrm{E}$-sorted portfolios range from 66 to 78 bps per month and are all statistically significant. The differences in CAPM alphas are even larger than the differences in excess returns, ranging from 79 to 91 bps per month. This is because high decile portfolios tend to have (slightly) lower CAPM betas than the low decile portfolios.

The left panel of Figure 2 visually shows that the CAPM alpha/valuation ratio relation is much stronger using $\mathrm{P} / \mathrm{E}$ sorts with global breakpoints than using $\mathrm{P} / \mathrm{B}$ sorts with regional breakpoints. The slope of the CAPM alpha/decile relation is much steeper overall, and also more consistent across deciles. 
Table 4 confirms that using earnings estimates when computing $\mathrm{P} / \mathrm{E}$ ratios further sharpens the value effect across global stocks. Differently from $\mathrm{P} / \mathrm{E}$ sorts, $\mathrm{P} / \mathrm{E}[\mathrm{E}]$ sorts generate monotonic relations between valuation ratio and excess returns, and valuation ratio and CAPM alphas. Moreover, the difference in excess returns across high and low deciles, as well the difference in CAPM alphas, is typically larger using $\mathrm{P} / \mathrm{E}[\mathrm{E}]$ sorts than using $\mathrm{P} / \mathrm{E}$ sorts. For Deciles 10 and 1 , using $\mathrm{P} / \mathrm{E}[\mathrm{E}]$ rather than $\mathrm{P} / \mathrm{E}$ increases the average excess return difference from 71 to 104 bps per month, and the CAPM alpha difference from 82 to 110 bps per month. Comparing the average of Deciles 10 and 9 to the average of Deciles 1 and 2 , using $\mathrm{P} / \mathrm{E}[\mathrm{E}]$ rather than $\mathrm{P} / \mathrm{E}$ raises the average return spread from 78 to 91 bps per month, and the CAPM alpha spread from 91 to 97 bps per month. ${ }^{24}$

The right panel of Figure 2 illustrates the very strong relation between $\mathrm{P} / \mathrm{E}[\mathrm{E}]$ and CAPM alphas, compared to the weak (and statistically insignificant) relation between $\mathrm{P} / \mathrm{B}$ and CAPM alphas. Note how the relation between $\mathrm{P} / \mathrm{E}[\mathrm{E}]$ and alphas (right panel) is monotonic, while the relation between $\mathrm{P} / \mathrm{E}$ and alphas (left panel) is not. Note also the much larger spread between extreme decile alphas using $\mathrm{P} / \mathrm{E}[\mathrm{E}]$ compared to using $\mathrm{P} / \mathrm{E}$. Thus, Figure 2 illustrates how using earnings estimates help sharpen the global value effect among large stocks.

\section{Regional results}

In this subsection we study stock returns at the regional rather than global level. First, we run Fama-MacBeth regressions of individual stock returns for each region at a time. Second, we sort stocks and form value-weighted portfolios within each of four geographical regions at a time (North America, Europe, Japan, and Asia-Pacific ex Japan) rather than globally.

\footnotetext{
${ }^{24}$ Table 4 shows that when we use historical earnings to compute $\mathrm{P} / \mathrm{E}$, the t-stats of our average excess returns and CAPM alpha are above three (for extreme deciles or extreme quintiles). These would qualify our results as a genuine anomaly according to Harvey et al. (2014) criterion. On the other hand, the t-stats are not above 3 when we use earnings estimates, which would weaken one's confidence in such results according to Harvey et al. (2014).
} 
As before, we focus on large stocks. In this section, a stock of a given region is labeled "large" if it is among the largest stocks that comprise $90 \%$ of the market capitalization in that region. ${ }^{25}$

Columns (1), (4), (7), and (10) of Table 5 show there is a value effect in large stocks in all four world regions. In North America, Europe, and Asia-Pacific, the coefficient on $E(+) / P$ is statistically significant, while the coefficient on $\ln (B / P)$ is statistically insignificant. That is, one can detect a value effect using $\mathrm{P} / \mathrm{E}$ ratios but not $\mathrm{P} / \mathrm{B}$ ratios. The opposite holds in Japan: the value effect can be detected using $\mathrm{P} / \mathrm{B}$ ratios but not $\mathrm{P} / \mathrm{E}$ ratios. Columns (2), (5), (8), and (11) control for size and momentum effects. The value effect (using $\mathrm{P} / \mathrm{E}$ or P/B) remains statistically significant in Europe, Asia-Pacific, and Japan, but becomes marginally statistically insignificant in North America (t-stat=1.60).

\section{TABLE 5}

Columns (3), (6), (9), and (12) of Table 5 shows that using earnings estimates to compute $\mathrm{P} / \mathrm{E}$ ratios sharpen the value effect among large stocks. In each of the four regions of the world, using $\mathrm{P} / \mathrm{E}[\mathrm{E}]$ allows us to uncover a significant value effect among large stocks. In all four regions - including North America - the coefficient on $E(E) / P$ is positive and statistically significant at the $5 \%$ level, even controlling for size and momentum.

Table 6 has our portfolio sort results. Starting at the end of June 1990, and for each region separately, we sort stocks into three portfolios based on their valuation ratios $(\mathrm{E}[\mathrm{E}] / \mathrm{P}, \mathrm{E} / \mathrm{P}$, or B/P). ${ }^{26}$ "Expensive" stocks are in the "Low" (bottom 30\%) portfolio. "Cheap" stocks

\footnotetext{
${ }^{25}$ The aggregate sample of regional stocks (pooling across the four regions) is not identical to the global sample in Sections 3 and 4. This is because, as in Fama and French's (2012) regional results, the size breakpoints are now computed within each region rather than globally. The aggregate world sample has 2,879 stocks per year, on average, compared to 2,752 in the global sample. The major difference between the samples is that there are more Asia-Pacific stocks (277 vs. 171 on average per year). Appendix Figure A-2 plots the minimum market cap over time for each of the four regions.

${ }^{26}$ We cannot sort stocks without analyst coverage by $\mathrm{E}[\mathrm{E}] / \mathrm{P}$. Like in the previous Section (see foonote 21), we assign these stocks to portfolios using an E/P sort.
} 
are in the "High" (top 30\%) portfolio. The mid 40\% stocks are in the Medium portfolios. Portfolios are value-weighted. Portfolios are rebalanced annually, at the end of June, when sorting on $\mathrm{E} / \mathrm{P}$ or $\mathrm{B} / \mathrm{P}$. Portfolios based on $\mathrm{E}[\mathrm{E}] / \mathrm{P}$ are rebalanced monthly.

\section{TABLE 6}

Table 6 shows that the constraint that portfolios cannot mix stocks of different regions has bite. In general, except for Asia-Pacific, the regional large-stock value premium is smaller than the global large-stock value premium in Table $2 .{ }^{27}$ Whereas we obtain an average return spread of 64 basis points per month with P/E sorts in Table 2 (global breakpoints), the corresponding regional $\mathrm{P} / \mathrm{E}$ sorts in Table 5 generate average return spreads of 29 bps per month in North America (t-stat=1.28), 45 bps per month in Europe (t-stat=2.86), 27 bps per month in Japan (t-stat=1.23), and 76 bps per month in Asia-Pacific (t-stat=3.68). These results show value investors benefit from a global perspective. This could be because stocks prices within a given region are more closely aligned with each other than with stock prices across regions, perhaps because some investors do not pay attention to stock prices in regions other than their own.

Table 6 shows that computing $\mathrm{P} / \mathrm{E}$ ratios using earnings estimates rather than historical earnings can help. In three of the four regions, the average return spread using $\mathrm{P} / \mathrm{E}[\mathrm{E}]$ is larger than average return spread using P/E. The differences are 39 vs. 29 bps in North America, 46 vs. 27 bps in Japan, and 119 vs. 76 bps in Asia-Pacific. In Europe, the return spreads using $\mathrm{P} / \mathrm{E}$ and $\mathrm{P} / \mathrm{E}[\mathrm{E}]$ are nearly identical, being equal to 44 vs. 45 bps respectively. Note that, even using earnings estimates, the value premium among large North American stocks is marginally statistically insignificant $(\mathrm{t}-\mathrm{stat}=1.61)$. However, the average return spread of 39 basis points per month appears economically substantial.

\footnotetext{
${ }^{27}$ We note that Asia-Pacific stocks in our regional results are on average substantially smaller than the Asia-Pacific stocks in our global results (see footnote 22 and compare Figures 1 and A.2). This size difference may explain why we find a relatively large value premium in the Asia-Pacific regional sort.
} 
Overall, the regional results in this section support the existence of value premium among large stocks not only globally, but also when adding the constraint that portfolios must be formed within each region separately (with the caveat that the value premium is economically large but marginally statistically insignificant in North America). However, the added regional constraint has bite: the regional value premium tends to be smaller than the global value premium, so that value investors benefit from a global perspective. Results also confirm that valuation ratios are not interchangeable. In particular, one cannot detect a value premium using $\mathrm{P} / \mathrm{B}$ in three of the four world regions, Japan being the exception. Finally, using $\mathrm{P} / \mathrm{E}$ ratios computed from earnings estimates sharpen the value effect not only globally but also within each of the four world regions.

\section{The global ROE effect: a cautionary example}

This section provides one an additional example that capturing the value premium using $\mathrm{P} / \mathrm{E}$ ratios instead of $\mathrm{P} / \mathrm{B}$ ratios can change inference about stock returns. We focus on the profitability (ROE)-effect in stock returns, first documented by Haugen and Baker (1996), and confirmed by Fama and French (2006), Hou, Xue, and Zhang (2012), and Wang and Yu (2013), among others. ${ }^{28}$ While these papers study the ROE effect within the United States, we, in line with the rest of the paper, study a global ROE effect pooling large stocks from around the world.

We note that $\mathrm{P} / \mathrm{E}, \mathrm{P} / \mathrm{B}$, and $\mathrm{ROE}$ are linked by the following accounting identity:

$$
\frac{P}{E}=\frac{P}{B} \times \frac{B}{E}=\frac{P}{B} \times \frac{1}{R O E}
$$

Now suppose that $\mathrm{P} / \mathrm{E}$ is a good signal for value while $\mathrm{P} / \mathrm{B}$ is not. That is, $\mathrm{P} / \mathrm{E}$ forecasts

\footnotetext{
${ }^{28}$ Novy-Marx (2013) studies a different profitability effect based on gross profits as a ratio of total assets as opposed to return on equity.
} 
stock returns cross-sectionally while $\mathrm{P} / \mathrm{B}$ doesn't. In that case, ROE likely forecasts stock returns as well, as it inherits the information contained in $\mathrm{P} / \mathrm{E}$ ratios. In other words, there is an ROE-effect in stock returns, but such effect is not independent from the value effect captured by $\mathrm{P} / \mathrm{E}$ ratios.

We calculate ROE for our sample stocks, using the accounting identity above, then winsorize it at the $1 \%$ level. The average ROE in our sample is 0.112 , the median is 0.111 , and the standard deviation is 0.185 . The correlations between the (post-winsorized) ROE and $\mathrm{E} / \mathrm{P}$ and $\mathrm{B} / \mathrm{P}$ are respectively 0.29 and -0.27 . Table 7 has results of Fama-McBeth regressions of individual stocks returns on stock characteristics. As in the previous sections, we follow Fama and French's (1992) variable definitions.

\section{TABLE 7}

The first column of Table 7 shows the ROE effect in our sample of large global stocks. The coefficient on ROE is positive and statistically significant, indicating that high ROE stocks tend to have higher subsequent returns than low ROE stocks. As it is standard in the literature, at this point researchers test whether a new characteristic that forecast returns has incremental information after controlling for other characteristics that are known to forecast returns. Following Fama and French (1992), the overwhelming majority of papers controls for the value effects using price-to-book ratios. Column (2) shows that the coefficient on ROE changes very little and remains statistically significant after controlling for price-tobook ratios. Column (3) shows that the coefficient on ROE remains statistically significant after simultaneously controlling for price-to-book ratios, size, and momentum.

However, Column (4) of Table 7 show that the results are not robust to controlling for value using $\mathrm{P} / \mathrm{E}$ rather than $\mathrm{P} / \mathrm{B}$ ratios. The coefficient on $\mathrm{ROE}$ becomes $65 \%$ smaller and is no longer statistically significant when $E(+) / P$ and $E / P$ Dummy are added to the 
right hand side of the regression equation. The coefficient on $E(+) / P$, on the other hand, is statistically significant. Column (5) shows this conclusion is unchanged when variables that capture size and momentum effects are added. Results in Columns (4) and (5) show that there is no independent ROE effect in the returns of large global stocks. The ROE effect in Columns (1), (2), and (3) arises simply because ROE inherits the stock return predictability contained in $\mathrm{P} / \mathrm{E}$ ratios. ${ }^{29}$

\section{Conclusion}

Fama and French's (2012) price-to-book sorts cannot detect a global value premium among large stocks in the last three decades. This paper shows that two simple departures from their methodology sorts restore an economically large and statistically significant value premium among large global stocks. We sort stocks by price-to-earnings $(\mathrm{P} / \mathrm{E})$ rather than by price-tobook $(\mathrm{P} / \mathrm{B})$ ratios, and use global rather than regional breakpoints. These changes increase the return spread between top $30 \%$ and bottom $30 \%$ value-weighted portfolios from 17 basis points per month (t-stat=1.09) to 64 basis points per month $(\mathrm{t}$-stat=2.61). Fama-McBeth regressions of individual stock returns confirm portfolio sort results. Because it is not confined to small and typically illiquid stocks, the value premium is a highly economically significant phenomenon that deserves its place at the center of Finance.

Our results corroborate recent research by Loughran and Wellman (2011) and Hou, Karolyi, and Kho (2011) showing that valuation ratios are not interchangeable. The highly influential Fama and French (1992) result that P/B ratios subsume information on other valuation ratios is specific to their particular sample (US stocks 1963-1990) and their particular collection of competing valuation ratios. In our sample of global stocks comprising nearly $90 \%$ of global market capitalization, there is no price-to-book effect in stock returns.

\footnotetext{
${ }^{29}$ In untabulated regressions, we exclude financial firms from the sample and reach the same conclusions.
} 
However, there is a strong value effect identified by using price-to-earnings ratios. The value effect is even stronger when $\mathrm{P} / \mathrm{E}$ ratios are computed with earnings estimates rather than historical earnings. We also show that inference whether there is an independent profitability (ROE) effect among large stocks globally depends on whether one controls for value using $\mathrm{P} / \mathrm{E}$ or $\mathrm{P} / \mathrm{B}$ ratios. Because valuation ratios are not interchangeable, researchers studying the value premium, or wishing to control for the value premium, should consider looking beyond $\mathrm{P} / \mathrm{B}$ ratios. 


\section{Appendix: Data Coverage}

We use global stock data from Datastream. Figure A-1 below plots the total stock market capitalization by region from January 2010 to June 2013. The figure includes both large and non-large stocks. By definition, the large stock sample covers $90 \%$ of total market cap as of June each year. The figure also plots total market cap from Fama and French (2012) and Asness and Frazzini (2011), using data generously available in Andrea Frazzini's and Ken French's webpages. Fama and French's (2012) data are from CRSP/Compustat for North America, and primarily from Bloomberg for the rest of the world. Asness and Frazzini's (2012) data are from CRSP for North America and XpressFeed for the rest of the world.

\section{FIGURE A - 1}

Figure A-1 shows our data coverage is comparable to Fama and French's (2012) and Asness and Frazzini's (2011). For North America and Japan, the three sample coverages are very close. Our total North American market cap is slightly higher than Fama and French's (2012) and Asness and Frazzini's (2011) from the mid 2000s on. This difference is likely because we do not discard OTC stocks. Datastream's does not keep historical information on the exchange in which a stock is traded, only the current exchange (or the last one, if a stock is no longer listed anywhere). The overwhelming majority of OTC North American stocks do not make into our large sample because they are too small (see Ang, Shtauber, and Tetlock 2013). Our Japanese market coverage is essentiallly identical to Asness and Frazzini's (2011), and both are slightly broader than Fama and French's (2012).

There are considerable data coverage differences among the three data sources in Europe and Asia-Pacific. In both cases, Asness and Frazzini's sample has substantially more total market capitalization than Fama and French's (2002). And in both cases our data coverage lies in between Fama and French's (2012) and Asness and Frazzini's (2011). 


\section{References}

Ali, Ashiq, Lee-Seok Hwang, and Mark A. Trombley, 2003. Arbitrage Risk and the Book-toMarket Anomaly. Journal of Financial Economics 69, 355-373.

Ang, Andrew, Assag A. Shtauber, and Paul C. Tetlock, 2013. Asset Pricing in the Dark: The Cross-Section of OTC Stocks. Review of Financial Studies 26, 2985-3028.

Asness, Clifford S. and Andrea Frazzini, 2013. The Devil in HML's Details. Journal of Portfolio Management 39, 49-68.

Asness, Cliffford S., Andrea Frazzini, Ronen Israel, and Tobias J. Moskowitz. 2014. Fact, Fiction, and Momentum Investing. Journal of Portfolio Management, forthcoming.

Basu, Sanjoy, 1977. Investment Performance of Common Stocks in Relation to Their PriceEarnings Ratios: A Test of the Efficient Market Hypothesis. Journal of Finance 32, 663-682.

Bradshaw, Mark T., and Richard G. Sloan, 2002. GAAP versus The Street: An Empirical Assessment of Two Alternative Definitions of Earnings. Journal of Accounting Research 40, 41-66.

Custodio, Claudia, 2014. Mergers and Acquisitions Accounting and the Diversification Discount. Journal of Finance 69, 219-240.

Easton, Peter D., Trevor S. Harris, and James A. Ohlson, 1992. Aggregate Accounting Earnings Can Explain Most of Security Returns. Journal of Accounting and Economics 15, 119-142.

Eisfeldt, Andrea and Dimitris Papanikolaou, 2013. Organization Capital and the Cross-Section of Expected Returns. Journal of Finance 68, 1365-1406.

FASB - Financial Accounting Standards Board, 2012. International Convergence of Accounting Standards: A Brief History. Available at FASB's website (http://www.fasb.org).

Fama, Eugene F. and Kenneth R. French, 1992. The Cross-Section of Expected Stock Returns. Journal of Finance 47: 427-465.

Fama, Eugene F. and Kenneth R. French, 1993. Common Risk Factors in the Returns on Stocks 
and Bonds. Journal of Financial Economics 33: 3-56.

Fama, Eugene F., and Kenneth R. French, 1998. Value versus Growth: The International Evidence. Journal of Finance 57: 1975-1999.

Fama, Eugene F., and Kenneth R. French, 2006. Profitability, Investment, and Average Returns. Journal of Financial Economics 82, 491-518.

Fama, Eugene F. and Kenneth R. French, 2008a. Dissecting Anomalies. Journal of Finance 63, 1653-1678.

Fama, Eugene F. and Kenneth R. French, 2008b. Average Returns, B/M, and Share Issues. Journal of Finance 63, 2971-2995.

Fama, Eugene F. and Kenneth R. French, 2012. Size, Value, and Momentum in International Stock Returns. Journal of Financial Economics 105, 457-472.

Fama, Eugene F. and Kenneth R. French, 2014. A Five-Factor Asset Pricing Model. Working paper.

Graham, Benjamin, and David Dodd, 1940. Security Analysis: Principles and Techniques. McGraw-Hill.

Harvey, Campbell R., Yan Liu, and Heqing Zhu, 2014. ... And the Cross-Section of Expected Returns. Working paper.

Haugen, Robert A., and Nardin L. Baker, 1996. Commonality in the Determinants of Expected Stock Returns. Journal of Financial Economics 41, 401-439.

Hou, Kewei, G. Andrew Karolyi, and Bong-Chan Kho, 2011. What Factors Drive Global Stock Returns? Review of Financial Studies 24: 2527-2574.

Hou, Kewei, Chen Xue, and Lu Zhang, 2012. Digesting Anomalies: An Investment Approach. Working paper.

Israel, Ronen and Tobias J. Moskowitz, 2013. The Role of Shorting, Firm Size, and Time on 
Market Anomalies. Journal of Financial Economics 108, 275-301.

Kecskes, Ambrus, Roni Michaely, and Kent L. Womack, 2013. It's the Earnings, Stupid! Analysts' Implicit Valuation Models and Their Recommendation Accuracy. Working paper.

Lakonishok, Josef, Andrei Shleifer, and Robert W, Vishny, 1994. Contrarian Investment, Extrapolation, and Risk. Journal of Finance 49:1541-1578.

Lev, Baruch, 2001. Intangibles: Management, Measurement, and Reporting. The Brookings Institution Press.

Loughran, Tim, 1997. Book-to-Market Across Firm Size, Exchange, and Seasonality: Is There an Effect?. Journal of Financial and Quantitative Analysis 32, 249-268.

Loughran, Tim and Todd Houge, 2006. Do Investors Capture the Value Premium? Financial Management 35, 5-19.

Loughran, Tim and Jay Wellman, 2011. New Evidence on the Relation between the Enterprise Multiple and Average Stock Returns. Journal of Financial and Quantitative Analysis 46, 16291650.

Michaely, Roni, and Kent L. Womack, 1999. Conflicts of Interest and the Credibility of Underwriter Analyst Recommendations. Review of Financial Studies 12, 653-686.

Nagel, Stefan, 2005. Short Sales, Institutional Investors, and the Book-to-Market Effect. Journal of Financial Economics 78, 277-309.

Novy-Marx, Robert, 2012. The Other Side of Value: The Gross Profitability Premium. Journal of Financial Economics 108, 1-28.

Penman, Stephen H., Francesco Reggiani, Scott A. Richardson, and Irem Tuna, 2014. An Accounting-Based Characteristic Model for Asset Pricing. Working paper.

Phalippou, Ludovic, 2008. Where Is the Value Premium? Financial Analysts Journal 64, 41-48. Rosenberg, Barr, Kenneth Reid, and Ronald Lanstein, 1985. Persuasive evidence of market 
innefficiency. Journal of Portfolio Management 11, 9-17.

Wang, Huijun and Jianfeng Yu, 2013. Dissecting the Profitability Premium. Working paper. 


\section{Table 1: Sample}

Table 1 contains summary statistics for our global sample at the end of June each year. The sample contains large stocks only, defined as the largest stocks that cumulatively comprise $90 \%$ of the global market capitalization at the end of June. $E[E] / P$ is the inverse $P / E$ ratio calculated from earnings estimates, as described in the text. Table displays averages over the 1990-2013 sample period. Data are from Datastream, Worldscope, and I/B/E/S.

\begin{tabular}{|c|c|c|c|c|c|c|c|c|c|}
\hline \multirow[b]{2}{*}{ Country } & \multirow[b]{2}{*}{ Region } & \multicolumn{5}{|c|}{ Full global sample } & \multicolumn{3}{|c|}{ Global sample with analyst coverage } \\
\hline & & $\begin{array}{c}\text { Number of } \\
\text { stocks }\end{array}$ & $\begin{array}{c}\% \text { of sample } \\
\text { market cap }\end{array}$ & Median E/P & Median B/P & $\begin{array}{c}\text { Subsequent } \\
\text { year excess } \\
\text { return (VW) }\end{array}$ & $\begin{array}{l}\text { Number of } \\
\text { stocks }\end{array}$ & $\begin{array}{l}\text { Analysts per } \\
\text { stock }\end{array}$ & $\begin{array}{l}\text { Median } \\
\mathrm{E}[\mathrm{E}] / \mathrm{P}\end{array}$ \\
\hline Canada & North America & 110 & 2.75 & 0.052 & 0.53 & 0.089 & 107 & 16.2 & 0.070 \\
\hline United States & North America & 1116 & 46.33 & 0.050 & 0.40 & 0.076 & 1086 & 17.3 & 0.067 \\
\hline Austria & Europe & 14 & 0.21 & 0.059 & 0.59 & 0.039 & 13 & 6.0 & 0.073 \\
\hline Belgium & Europe & 24 & 0.68 & 0.071 & 0.69 & 0.065 & 23 & 6.5 & 0.079 \\
\hline Denmark & Europe & 17 & 0.33 & 0.053 & 0.47 & 0.082 & 16 & 8.7 & 0.067 \\
\hline Finland & Europe & 16 & 0.44 & 0.038 & 0.76 & 0.127 & 16 & 2.5 & 0.085 \\
\hline France & Europe & 117 & 4.76 & 0.056 & 0.56 & 0.070 & 111 & 10.5 & 0.069 \\
\hline Germany & Europe & 100 & 3.97 & 0.047 & 0.45 & 0.057 & 87 & 12.2 & 0.064 \\
\hline Greece & Europe & 12 & 0.19 & 0.084 & 0.52 & 0.021 & 12 & 2.0 & 0.107 \\
\hline Ireland & Europe & 11 & 0.22 & 0.068 & 0.44 & 0.060 & 11 & 6.0 & 0.082 \\
\hline Italy & Europe & 60 & 1.85 & 0.053 & 0.68 & 0.014 & 55 & 9.2 & 0.068 \\
\hline Netherlands & Europe & 38 & 1.89 & 0.061 & 0.47 & 0.076 & 37 & 17.6 & 0.079 \\
\hline Norway & Europe & 15 & 0.36 & 0.073 & 0.58 & 0.085 & 15 & 7.4 & 0.089 \\
\hline Portugal & Europe & 11 & 0.19 & 0.072 & 0.52 & 0.045 & 11 & 1.0 & 0.089 \\
\hline Spain & Europe & 48 & 1.65 & 0.069 & 0.55 & 0.062 & 47 & 13.4 & 0.078 \\
\hline Sweden & Europe & 35 & 0.91 & 0.065 & 0.56 & 0.105 & 34 & 7.6 & 0.076 \\
\hline Switzerland & Europe & 46 & 2.33 & 0.058 & 0.53 & 0.090 & 44 & 13.2 & 0.071 \\
\hline United Kingdom & Europe & 210 & 8.42 & 0.062 & 0.42 & 0.061 & 207 & 12.9 & 0.077 \\
\hline Australia & Asia-Pacific ex Japan & 71 & 1.89 & 0.061 & 0.52 & 0.082 & 70 & 12.2 & 0.072 \\
\hline Hong Kong & Asia-Pacific ex Japan & 64 & 2.28 & 0.074 & 0.68 & 0.123 & 60 & 16.9 & 0.085 \\
\hline New Zealand & Asia-Pacific ex Japan & 5 & 0.07 & 0.063 & 0.69 & 0.068 & 5 & 9.0 & 0.072 \\
\hline Singapore & Asia-Pacific ex Japan & 30 & 0.60 & 0.056 & 0.56 & 0.080 & 29 & 18.4 & 0.064 \\
\hline Japan & Japan & 582 & 17.68 & 0.032 & 0.58 & -0.003 & 411 & 4.3 & 0.044 \\
\hline Global & & 2752 & 100 & 0.047 & 0.46 & 0.049 & 2506 & 12.6 & 0.066 \\
\hline
\end{tabular}


Table 2: Global portfolio sorts

Table 2 contains statistics of global portfolios based on valuation ratio sorts. The portfolios only have large stocks. At the end of June each year, stocks across the globe are sorted into three portfolios based on E/P or B/P, using either global or regional breakpoints. Low, Medium, and High refer to bottom $30 \%$, medium $40 \%$, and top $30 \%$ respectively. Portfolios are value-weighted, and held for the subsequent year. Excess returns are dollardenominated, and defined in excess of the 1-month T-bill. Panels A and B have summary statistics of monthly excess returns, average number of stocks per year, and average of median E/P and B/P. Panel C has World CAPM alphas and betas, and pairwise correlations, for the High minus Low portfolios. T-statistics are robust to heteroskedasticity (White). The sample period is July 1990-June 2013.

Panel A

\begin{tabular}{|c|c|c|c|c|c|c|}
\hline & & & Low & Medium & High & High - Low \\
\hline \multirow[t]{2}{*}{$\begin{array}{c}\text { E/P } \\
\text { Global breakpoints }\end{array}$} & VW Excess Return & $\begin{array}{l}\text { avg. } \\
\text { std.dev. } \\
\text { t-mean }\end{array}$ & $\begin{array}{r}0.0004 \\
0.059 \\
0.10\end{array}$ & $\begin{array}{r}0.0043 \\
0.040 \\
1.79\end{array}$ & $\begin{array}{r}0.0068 \\
0.044 \\
2.55\end{array}$ & $\begin{array}{c}0.0064 * * * \\
0.041 \\
2.61\end{array}$ \\
\hline & \multicolumn{2}{|c|}{ Earnings Yield (E/P) (median) } & 0.011 & 0.047 & 0.086 & \\
\hline \multirow{2}{*}{$\begin{array}{l}\text { B/P, } \\
\text { Regional breakpoints } \\
\text { (Fama-French 2012) }\end{array}$} & VW Excess Return & $\begin{array}{l}\text { avg. } \\
\text { std.dev. } \\
\text { t-mean }\end{array}$ & $\begin{array}{r}0.0032 \\
0.046 \\
1.17\end{array}$ & $\begin{array}{r}0.0044 \\
0.044 \\
1.69\end{array}$ & $\begin{array}{r}0.0049 \\
0.047 \\
1.72\end{array}$ & $\begin{array}{r}0.0017 \\
0.026 \\
1.09\end{array}$ \\
\hline & \multicolumn{2}{|c|}{ Book to Price (B/P) (median) } & 0.203 & 0.457 & 0.832 & \\
\hline & \multicolumn{2}{|c|}{ Number of stocks (avg.) } & $\begin{array}{l}825 \\
276\end{array}$ & $\begin{array}{r}1102 \\
276\end{array}$ & $\begin{array}{l}825 \\
276\end{array}$ & 276 \\
\hline
\end{tabular}

Panel B

\begin{tabular}{|c|c|c|c|c|c|c|}
\hline & & & Low & Medium & High & High - Low \\
\hline \multirow{4}{*}{$\begin{array}{c}E / P, \\
\text { Regional breakpoints }\end{array}$} & \multirow{3}{*}{ VW Excess Return } & avg. & 0.0020 & 0.0043 & 0.0057 & \multirow{4}{*}{$\begin{array}{c}0.0037 \\
0.026 \\
2.38\end{array}$} \\
\hline & & std.dev. & 0.054 & 0.041 & 0.044 & \\
\hline & & t-mean & 0.61 & 1.72 & 2.17 & \\
\hline & \multicolumn{2}{|c|}{ Earnings Yield (E/P) (median) } & 0.011 & 0.050 & 0.086 & \\
\hline \multirow{6}{*}{$\begin{array}{c}\text { B/P, } \\
\text { Global breakpoints }\end{array}$} & \multirow{3}{*}{ VW Excess Return } & avg. & 0.0035 & 0.0042 & 0.0050 & \multirow{4}{*}{$\begin{array}{r}0.0015 \\
0.030 \\
0.86\end{array}$} \\
\hline & & std.dev. & 0.047 & 0.044 & 0.046 & \\
\hline & & t-mean & 1.22 & 1.56 & 1.81 & \\
\hline & \multicolumn{2}{|c|}{ Book to Price (B/P) (median) } & 0.203 & 0.457 & 0.841 & \\
\hline & \multirow{2}{*}{\multicolumn{2}{|c|}{ Number of stocks (avg.) }} & 825 & 1102 & 825 & \\
\hline & & & 276 & 276 & 276 & 276 \\
\hline
\end{tabular}


Table 2: Global portfolio sorts - continued

\begin{tabular}{|c|c|c|c|c|c|c|c|}
\hline & \multirow[b]{2}{*}{ CAPM $\beta$} & \multirow[b]{2}{*}{$\mathrm{CAPM}_{\alpha}$} & \multicolumn{5}{|c|}{ Pairwise Correlations } \\
\hline & & & $\begin{array}{r}\mathrm{P} / \mathrm{E}, \\
\text { Global } \\
\end{array}$ & $\begin{array}{r}\mathrm{P} / \mathrm{B}, \\
\text { Regional } \\
\end{array}$ & $\begin{array}{r}\mathrm{P} / \mathrm{E}, \\
\text { Regional } \\
\end{array}$ & $\begin{array}{r}\text { P/B, } \\
\text { Global } \\
\end{array}$ & Mkt-Rf \\
\hline $\mathrm{HML}_{\mathrm{B}}$ with $\mathrm{P} / \mathrm{E}$, Global & $\begin{array}{l}-0.33^{* * *} \\
(-4.62)\end{array}$ & $\begin{array}{l}0.0077 \text { *** } \\
(-3.34)\end{array}$ & 1 & & & & \\
\hline $\mathrm{HML}_{\mathrm{B}}$ with $\mathrm{P} / \mathrm{B}$, Regional & $\begin{array}{r}0.02 \\
(0.32)\end{array}$ & $\begin{array}{r}0.0016 \\
(1.03)\end{array}$ & 0.51 & 1 & & & \\
\hline $\mathrm{HML}_{\mathrm{B}}$ with $\mathrm{P} / \mathrm{E}$, Regional & $\begin{array}{l}-0.22 * * * \\
(-5.10)\end{array}$ & $\begin{array}{l}0.0046 \text { *** } \\
(3.08)\end{array}$ & 0.78 & 0.64 & 1 & & \\
\hline $\mathrm{HML}_{\mathrm{B}}$ with $\mathrm{P} / \mathrm{B}$, Global & $\begin{array}{r}-0.05 \\
(-0.97)\end{array}$ & $\begin{array}{r}0.0017 \\
(0.97)\end{array}$ & 0.60 & 0.83 & 0.51 & 1 & \\
\hline $\begin{array}{c}\text { Global market excess return } \\
\text { (Mkt-Rf) }\end{array}$ & 1 & 0 & -0.36 & 0.03 & -0.39 & -0.08 & 1 \\
\hline
\end{tabular}


Table 3: Global Fama-MacBeth regressions

Table 3 contains results of Fama-MacBeth regressions of monthly returns of individual stocks. Stocks are pooled across the globe. The sample has large stocks only. The number of large stocks ( $\mathrm{N}$ in the table) is as of the end of June each year. If historical earnings are positive, $E(+) / P$ is the inverse of the price-earnings ratio. If historical earnings are not positive, $E(+) / P$ is equal to zero and $E / P$ Dummy is equal to 1 . $E[E] / P$ is the inverse of the priceearnings ratio computed using earnings estimates, as described in the text. Dependent variables are winsorized at the $1 \%$ level in both tails. Panel A has summary statistics. Market cap is in billions of dollars. Panel B has regressions results. Standard errors are corrected for heteroskedasticity and autocorrelation (Newey-West, one lag). The sample period is July 1990-June 2013.

Panel A

\begin{tabular}{r|rrrrrrr}
\hline & $\begin{array}{r}\text { Subsequent } \\
\text { monthly } \\
\text { return }\end{array}$ & $\mathrm{E}(+) / \mathrm{P}$ & $\begin{array}{r}\mathrm{E} / \mathrm{P} \\
\text { Dummy }\end{array}$ & $\mathrm{B} / \mathrm{P}$ & Market Cap & Prior Return & $\mathrm{E}[\mathrm{E}] / \mathrm{P}$ \\
\hline Mean & 0.0078 & 0.052 & 0.098 & 0.519 & 6.84 & 0.129 & 0.068 \\
St.Dev. & 0.1115 & 0.039 & 0.297 & 0.346 & 12.95 & 0.387 & 0.034 \\
Median & 0.0065 & 0.047 & 0 & 0.452 & 2.53 & 0.091 & 0.066 \\
\hline Average N & 2752 & 2752 & 2752 & 2752 & 2752 & 2715 & 2507 \\
$\mathrm{~T}$ & 276 & 276 & 276 & 276 & 276 & 276 & 276
\end{tabular}

Panel B

\begin{tabular}{|c|c|c|c|c|c|c|c|c|}
\hline & \multicolumn{5}{|c|}{ Full global sample } & \multicolumn{3}{|c|}{$\begin{array}{c}\text { Global sample with analyst } \\
\text { coverage }\end{array}$} \\
\hline & (1) & (2) & (3) & (4) & (5) & (6) & (7) & (8) \\
\hline$E(+) / P$ & $\begin{array}{l}0.0670 * \star \star \\
(2.76)\end{array}$ & & $\begin{array}{l}0.0645 * * * \\
(2.81)\end{array}$ & $\begin{array}{c}0.0527 \\
(2.45)\end{array}$ & $\begin{array}{c}0.0503 \text { ** } \\
(2.43)\end{array}$ & & & $\begin{array}{r}0.0111 \\
(0.97)\end{array}$ \\
\hline E/P Dummy & $\begin{array}{r}0.0011 \\
(0.55)\end{array}$ & & $\begin{array}{r}0.0010 \\
(0.43)\end{array}$ & $\begin{array}{r}0.0002 \\
(0.12)\end{array}$ & $\begin{array}{r}0.0000 \\
(0.02)\end{array}$ & & & $\begin{array}{r}-0.0007 \\
(-0.41)\end{array}$ \\
\hline $\ln (B / P)$ & & $\begin{array}{r}0.0010 \\
(0.88)\end{array}$ & $\begin{array}{r}-0.0002 \\
(-0.23)\end{array}$ & & $\begin{array}{l}0.0000 \\
(-0.01)\end{array}$ & & $\begin{array}{r}-0.0005 \\
(-0.59)\end{array}$ & $\begin{array}{r}-0.0006 \\
(-0.71)\end{array}$ \\
\hline In(Market Cap) & & & & $\begin{array}{r}-0.0004 \\
(-1.11)\end{array}$ & $\begin{array}{r}-0.0004 \\
(-1.01)\end{array}$ & & $\begin{array}{r}-0.0004 \\
(-1.05)\end{array}$ & $\begin{array}{r}-0.0005 \\
(-1.21)\end{array}$ \\
\hline In(1+Prior Return) & & & & $\begin{array}{r}0.0055 \\
(1.37)\end{array}$ & $\begin{array}{r}0.0052 \\
(1.32)\end{array}$ & & $\begin{array}{r}0.0062 \\
(1.63)\end{array}$ & $\begin{array}{r}0.0059 \\
(1.57)\end{array}$ \\
\hline$E[E] / P$ & & & & & & $\begin{array}{l}0.0895 * * \\
(2.41)\end{array}$ & $\begin{array}{l}0.0819 \text { ** } \\
(2.57)\end{array}$ & $\begin{array}{l}0.0709 \text { ** } \\
(2.21)\end{array}$ \\
\hline Intercept & $\begin{array}{r}0.0043 \\
(1.26)\end{array}$ & $\begin{array}{l}0.0087 * * * \\
(2.77)\end{array}$ & $\begin{array}{r}0.0044 \\
(1.32)\end{array}$ & $\begin{array}{r}0.0030 \\
(0.97)\end{array}$ & $\begin{array}{r}0.0033 \\
(1.07)\end{array}$ & $\begin{array}{r}0.0026 \\
(0.75)\end{array}$ & $\begin{array}{r}0.0005 \\
(0.16)\end{array}$ & $\begin{array}{r}0.0007 \\
(0.22)\end{array}$ \\
\hline Average $\mathrm{N}$ & 2752 & 2752 & 2752 & 2715 & 2715 & 2507 & 2476 & 2476 \\
\hline Average $\mathrm{R}^{2}$ & 0.024 & 0.014 & 0.033 & 0.057 & 0.064 & 0.028 & 0.067 & 0.073 \\
\hline $\mathrm{T}$ & 276 & 276 & 276 & 276 & 276 & 276 & 276 & 276 \\
\hline
\end{tabular}




\section{Table 4: Global decile sorts}

Table 4 displays excess returns and World CAPM alphas of global portfolios. The portfolios contain large stocks only. Portfolios are value-weighted, and formed by sorting global stocks into decile portfolios based on valuation ratios $P / E, P / E[E]$, and $P / B$. $P / E[E]$ is the price-earnings ratio using earnings estimates, as described in the text. $\mathrm{P} / \mathrm{E}$ and $\mathrm{P} / \mathrm{E}[\mathrm{E}]$ portfolios are based on global breakpoints, while $\mathrm{P} / \mathrm{B}$ portfolios are based on $\mathrm{P} / \mathrm{B}$ use regional breakpoints, as in Fama and French (2012). $P / E$ and $P / B$ portfolios are annually rebalanced, at the end of June each year. $P / E[E]$ portfolios are monthly rebalanced. The differences between Deciles 10 and 1 is also reported, along with the differences between the averages of Deciles 9 and 10 and the average of Deciles 1 and 2 , and the average between Deciles 8 through 10 and the average of Deciles 1 through 3. Standard errors are robust to heteroskedasticity. The sample period is July 1990-June 2013.

\begin{tabular}{|c|c|c|c|c|c|c|c|c|c|c|c|c|c|c|}
\hline & & & & & Decile & portfolios ( & alue-weight & ed) & & & & & Differences & \\
\hline & & (1) & (2) & (3) & (4) & (5) & (6) & (7) & (8) & (9) & (10) & $\begin{array}{c}(10)- \\
(1) \\
\end{array}$ & $\begin{array}{c}(10+9)- \\
(1+2) \\
\end{array}$ & $\begin{array}{c}(10+9+8)- \\
(1+2+3) \\
\end{array}$ \\
\hline P/E, & Excess return & $\begin{array}{r}0.0009 \\
(0.24)\end{array}$ & $\begin{array}{r}-0.0012 \\
(-0.30)\end{array}$ & $\begin{array}{r}0.0011 \\
(0.33)\end{array}$ & $\begin{array}{r}0.0024 \\
(0.86)\end{array}$ & $\begin{array}{r}0.0037 \\
(1.40)\end{array}$ & $\begin{array}{c}0.0049 * * \\
(2.04)\end{array}$ & $\begin{array}{c}0.0061 \text { ** } \\
(2.48)\end{array}$ & $\begin{array}{c}0.0054 \text { ** } \\
(2.18)\end{array}$ & $\begin{array}{l}0.0073 \text { *** } \\
(2.72)\end{array}$ & $\begin{array}{c}0.0080 * * * \\
(2.66)\end{array}$ & $\begin{array}{l}0.0071 \text { *** } \\
(3.03)\end{array}$ & $\begin{array}{l}0.0078 \text { *** } \\
(3.06)\end{array}$ & $\begin{array}{l}0.0066 \text { *** } \\
(2.74)\end{array}$ \\
\hline $\begin{array}{c}\text { global } \\
\text { breakpoints }\end{array}$ & $\mathrm{CAPM}_{\alpha}$ & $\begin{array}{l}-0.0041 \text { *** } \\
(-3.11)\end{array}$ & $\begin{array}{c}*-0.0063 \\
(-3.43)\end{array}$ & $\begin{array}{c}-0.0034 \text { ** } \\
(-2.42)\end{array}$ & $\begin{array}{r}-0.0014 \\
(1.33)\end{array}$ & $\begin{array}{r}0.0000 \\
(-0.05)\end{array}$ & $\begin{array}{c}0.0016 \text { * } \\
(1.92)\end{array}$ & $\begin{array}{l}0.0028 \text { *** } \\
(2.88)\end{array}$ & $\begin{array}{c}0.0021 \text { ** } \\
(1.97)\end{array}$ & $\begin{array}{l}0.0038 \text { *** } \\
(3.14)\end{array}$ & $\begin{array}{c}0.0041^{* * *} \\
(2.88)\end{array}$ & $\begin{array}{l}0.0082 \text { *** } \\
(3.67)\end{array}$ & $\begin{array}{l}0.0091 \text { *** } \\
(3.81)\end{array}$ & $\begin{array}{c}0.0079 \text { *** } \\
(3.47)\end{array}$ \\
\hline $\mathrm{P} / \mathrm{E}[\mathrm{E}]$ & Excess return & $\begin{array}{r}-0.0010 \\
(-0.24)\end{array}$ & $\begin{array}{r}0.0001 \\
(0.03)\end{array}$ & $\begin{array}{r}0.0024 \\
(0.88)\end{array}$ & $\begin{array}{r}0.0027 \\
(1.09)\end{array}$ & $\begin{array}{c}0.0045 \text { * } \\
(1.82)\end{array}$ & $\begin{array}{c}0.0051 * * \\
(2.07)\end{array}$ & $\begin{array}{c}0.0060 \text { ** } \\
(2.36)\end{array}$ & $\begin{array}{c}0.0064 \text { ** } \\
(2.27)\end{array}$ & $\begin{array}{l}0.0080 \text { *** } \\
(2.65)\end{array}$ & $\begin{array}{c}0.0093 \text { ** } \\
(2.39)\end{array}$ & $\begin{array}{c}0.0104 \text { ** } \\
(2.54)\end{array}$ & $\begin{array}{l}0.0091 \\
(2.68)\end{array}$ & $\begin{array}{c}0.0074 \text { *** } \\
(2.61)\end{array}$ \\
\hline breakpoints & CAPM $\alpha$ & $\begin{array}{c}-0.0064 \text { *** } \\
(-2.77)\end{array}$ & $\begin{array}{c}*-0.0043 \text { *** } \\
(-2.52)\end{array}$ & $\begin{array}{r}-0.0013 \\
(-1.22)\end{array}$ & $\begin{array}{c}-0.0007^{* * *} \\
(-0.87)\end{array}$ & $\begin{array}{r}0.0011 \\
(1.28)\end{array}$ & $\begin{array}{c}0.0017 \text { * } \\
(1.94)\end{array}$ & $\begin{array}{c}0.0026 \text { ** } \\
(2.34)\end{array}$ & $\begin{array}{c}0.0027 \text { ** } \\
(2.08)\end{array}$ & $\begin{array}{l}0.0041 \text { *** } \\
(2.82)\end{array}$ & $\begin{array}{c}0.0046 \text { ** } \\
(2.13)\end{array}$ & $\begin{array}{l}0.0110 \text { *** } \\
(2.71)\end{array}$ & $\begin{array}{l}0.0097 \text { *** } \\
(2.84)\end{array}$ & $\begin{array}{c}0.0078 \text { *** } \\
(2.72)\end{array}$ \\
\hline $\begin{array}{l}\mathrm{P} / \mathrm{B} \\
\text { regional }\end{array}$ & Excess return & $\begin{array}{r}0.0022 \\
(0.73)\end{array}$ & $\begin{array}{r}0.0033 \\
(1.18)\end{array}$ & $\begin{array}{r}0.0034 \\
(1.24)\end{array}$ & $\begin{array}{r}0.0038 \\
(1.43)\end{array}$ & $\begin{array}{c}0.0044 \text { * } \\
(1.66)\end{array}$ & $\begin{array}{c}0.0051 \text { * } \\
(1.91)\end{array}$ & $\begin{array}{c}0.0051 \text { * } \\
(1.85)\end{array}$ & $\begin{array}{r}0.0044 \\
(1.60)\end{array}$ & $\begin{array}{c}0.0050 \text { * } \\
(1.75)\end{array}$ & $\begin{array}{c}0.0055 \text { * } \\
(1.74)\end{array}$ & $\begin{array}{r}0.0033 \\
(1.36)\end{array}$ & $\begin{array}{r}0.0025 \\
(1.34)\end{array}$ & $\begin{array}{r}0.0020 \\
(1.26)\end{array}$ \\
\hline $\begin{array}{l}\text { breakpoints } \\
\text { (Fama- } \\
\text { French 2012) }\end{array}$ & CAPM $\alpha$ & $\begin{array}{r}-0.0018 \\
(-1.27)\end{array}$ & $\begin{array}{l}-0.0006 \text { *** } \\
(-0.70)\end{array}$ & $\begin{array}{r}-0.0004 \\
(-0.50)\end{array}$ & $\begin{array}{r}0.0000 \\
(0.00)\end{array}$ & $\begin{array}{r}0.0006 \\
(1.01)\end{array}$ & $\begin{array}{c}0.0013 \text { * } \\
(1.75)\end{array}$ & $\begin{array}{r}0.0012 \\
(1.51)\end{array}$ & $\begin{array}{r}0.0006 \\
(0.66)\end{array}$ & $\begin{array}{r}0.0011 \\
(1.04)\end{array}$ & $\begin{array}{r}0.0013 \\
(0.94)\end{array}$ & $\begin{array}{r}0.0031 \\
(1.22)\end{array}$ & $\begin{array}{r}0.0024 \\
(1.23)\end{array}$ & $\begin{array}{r}0.0019 \\
(1.18)\end{array}$ \\
\hline & $\mathrm{T}$ & 276 & 276 & 276 & 276 & 276 & 276 & 276 & 276 & 276 & 276 & 276 & 276 & 276 \\
\hline
\end{tabular}


Table 5: Regional Fama-MacBeth regressions

Table 5 contains results of Fama-MacBeth regressions of monthly returns of individual stocks. Stocks are pooled across each of four world regions. The sample has large stocks only. The number of large stocks ( $N$ in the table) is as of the end of June each year. If historical earnings are positive, $E(+) / P$ is the inverse of the price-earnings ratio. If historical earnings are not positive, $E(+) / P$ is equal to zero and $E / P$ Dummy is equal to 1 . $E[E] / P$ is the inverse of the price-earnings ratio computed using earnings estimates, as described in the text. Dependent variables are winsorized at the $1 \%$ level in both tails. Panel $\mathrm{A}$ has summary statistics. Market cap is in billions of dollars. Panel B has regressions results. Standard errors are corrected for heteroskedasticity and autocorrelation (Newey-West, one lag). The sample period is July 1990-June 2013.

\begin{tabular}{|c|c|c|c|c|c|c|c|c|c|c|c|c|}
\hline & \multicolumn{3}{|c|}{ North America } & \multicolumn{3}{|c|}{ Europe } & \multicolumn{3}{|c|}{ Japan } & \multicolumn{3}{|c|}{ Asia-Pacific } \\
\hline & $(1)$ & $(2)$ & (3) & (4) & (5) & (6) & (7) & (8) & (9) & (10) & (11) & (12) \\
\hline$E(+) / P$ & $\begin{array}{c}0.0301 \text { ** } \\
(2.00)\end{array}$ & $\begin{array}{r}0.0230 \\
(1.60)\end{array}$ & & $\begin{array}{l}0.0466 \text { *** } \\
(3.87)\end{array}$ & $\begin{array}{c}0.0369 * * * \\
(3.61)\end{array}$ & & $\begin{array}{r}0.0286 \\
(1.11)\end{array}$ & $\begin{array}{r}0.0108 \\
(0.49)\end{array}$ & & $\begin{array}{c}0.0399 * * * \\
(2.65)\end{array}$ & $\begin{array}{c}0.0276 \text { * } \\
(1.95)\end{array}$ & \\
\hline E/P Dummy & $\begin{array}{l}0.0000 \\
(-0.01)\end{array}$ & $\begin{array}{r}-0.0011 \\
(-0.60)\end{array}$ & & $\begin{array}{r}-0.0018 \\
(-0.88)\end{array}$ & $\begin{array}{r}-0.0013 \\
(-0.80)\end{array}$ & & $\begin{array}{r}0.0010 \\
(0.41)\end{array}$ & $\begin{array}{r}0.0001 \\
(0.06)\end{array}$ & & $\begin{array}{l}-0.0042 \\
(-1.293)\end{array}$ & $\begin{array}{r}-0.0040 \\
(-1.31)\end{array}$ & \\
\hline $\ln (B / P)$ & $\begin{array}{r}0.0002 \\
(0.18)\end{array}$ & $\begin{array}{r}0.0001 \\
(0.12)\end{array}$ & $\begin{array}{r}-0.0004 \\
(-0.47)\end{array}$ & $\begin{array}{r}0.0005 \\
(0.59)\end{array}$ & $\begin{array}{r}0.0003 \\
(0.45)\end{array}$ & $\begin{array}{r}0.0000 \\
(0.05)\end{array}$ & $\begin{array}{c}0.0029 \text { ** } \\
(2.46)\end{array}$ & $\begin{array}{l}0.0034 \text { *** } \\
(3.31)\end{array}$ & $\begin{array}{c}0.0033 \text { *** } \\
(3.27)\end{array}$ & $\begin{array}{r}0.0014 \\
(1.35)\end{array}$ & $\begin{array}{r}0.0010 \\
(1.03)\end{array}$ & $\begin{array}{r}0.0001 \\
(0.09)\end{array}$ \\
\hline In(Market Cap) & & $\begin{array}{l}-0.0011 \text { ** } \\
(-2.31)\end{array}$ & $\begin{array}{l}-0.0010 \text { ** } \\
(-2.02)\end{array}$ & & $\begin{array}{r}0.0002 \\
(0.51)\end{array}$ & $\begin{array}{r}0.0003 \\
(0.68)\end{array}$ & & $\begin{array}{r}0.0002 \\
(0.40)\end{array}$ & $\begin{array}{r}0.0001 \\
(0.09)\end{array}$ & & $\begin{array}{r}-0.0002 \\
(-0.36)\end{array}$ & $\begin{array}{r}-0.0001 \\
(-0.14)\end{array}$ \\
\hline In(1+Prior Return) & & $\begin{array}{l}0.0061 \\
(1.532)\end{array}$ & $\begin{array}{c}0.0067 \text { * } \\
(1.71)\end{array}$ & & $\begin{array}{c}0.0105 * * \\
(2.39)\end{array}$ & $\begin{array}{l}0.0118 \text { *** } \\
(2.79)\end{array}$ & & $\begin{array}{r}0.0013 \\
(0.29)\end{array}$ & $\begin{array}{r}0.0000 \\
(0.01)\end{array}$ & & $\begin{array}{c}0.0102 \text { ** } \\
(2.12)\end{array}$ & $\begin{array}{c}0.0129 \\
(2.96)\end{array}$ \\
\hline$E[E] / P$ & & & $\begin{array}{c}0.0595 \text { ** } \\
(2.20)\end{array}$ & & & $\begin{array}{c}0.0630 \text { ** } \\
(2.50)\end{array}$ & & & $\begin{array}{c}0.0659 \text { ** } \\
(1.97)\end{array}$ & & & $\begin{array}{c}0.0786 \text { *** } \\
(3.01)\end{array}$ \\
\hline Intercept & $\begin{array}{l}0.0091 \text { *** } \\
(2.88)\end{array}$ & $\begin{array}{c}0.0082 \text { *** } \\
(2.63)\end{array}$ & $\begin{array}{r}0.0047 \\
(1.59)\end{array}$ & $\begin{array}{r}0.0058 \\
(1.53)\end{array}$ & $\begin{array}{r}0.0029 \\
(0.82)\end{array}$ & $\begin{array}{r}0.0001 \\
(0.02)\end{array}$ & $\begin{array}{r}0.0044 \\
(1.15)\end{array}$ & $\begin{array}{r}0.0029 \\
(0.83)\end{array}$ & $\begin{array}{r}0.0014 \\
(0.36)\end{array}$ & $\begin{array}{r}0.0089 \\
(2.00)\end{array}$ & $\begin{array}{r}0.0052 \\
(1.30)\end{array}$ & $\begin{array}{r}0.0006 \\
(0.16)\end{array}$ \\
\hline Average $\mathrm{N}$ & 1124 & 1108 & 1082 & 734 & 721 & 689 & 745 & 740 & 555 & 277 & 273 & 257 \\
\hline Average $\mathrm{R}^{2}$ & 0.026 & 0.058 & 0.060 & 0.023 & 0.061 & 0.067 & 0.029 & 0.073 & 0.076 & 0.022 & 0.057 & 0.067 \\
\hline $\mathrm{T}$ & 276 & 276 & 276 & 276 & 276 & 276 & 276 & 276 & 276 & 276 & 276 & 276 \\
\hline
\end{tabular}


Table 6: Regional portfolio sorts

Table 6 contains statistics of regional portfolios based on sorting stocks on valuation ratios. Portfolios contain large stocks only. At the end of June each year, stocks within each of four regions are sorted into three portfolios based on $E / P, B / P$, or $E[E] / P$, using regional breakpoints. Low, Medium, and High refer to bottom $30 \%$, medium $40 \%$, and top $30 \%$ respectively. $E[E] / P$ is the inverse of the price-earnings ratio computed using earnings estimates, as described in the text. Portfolios are value-weighted, held for the subsequent year. Excess returns are dollar-denominated, and defined in excess of the 1-month T-bill. Panels A and B have summary statistics for monthly excess returns, average number of stocks per year, and average of yearly (median) E/P, B/P, and E[E]/P. The sample period is July 1990-June 2013.

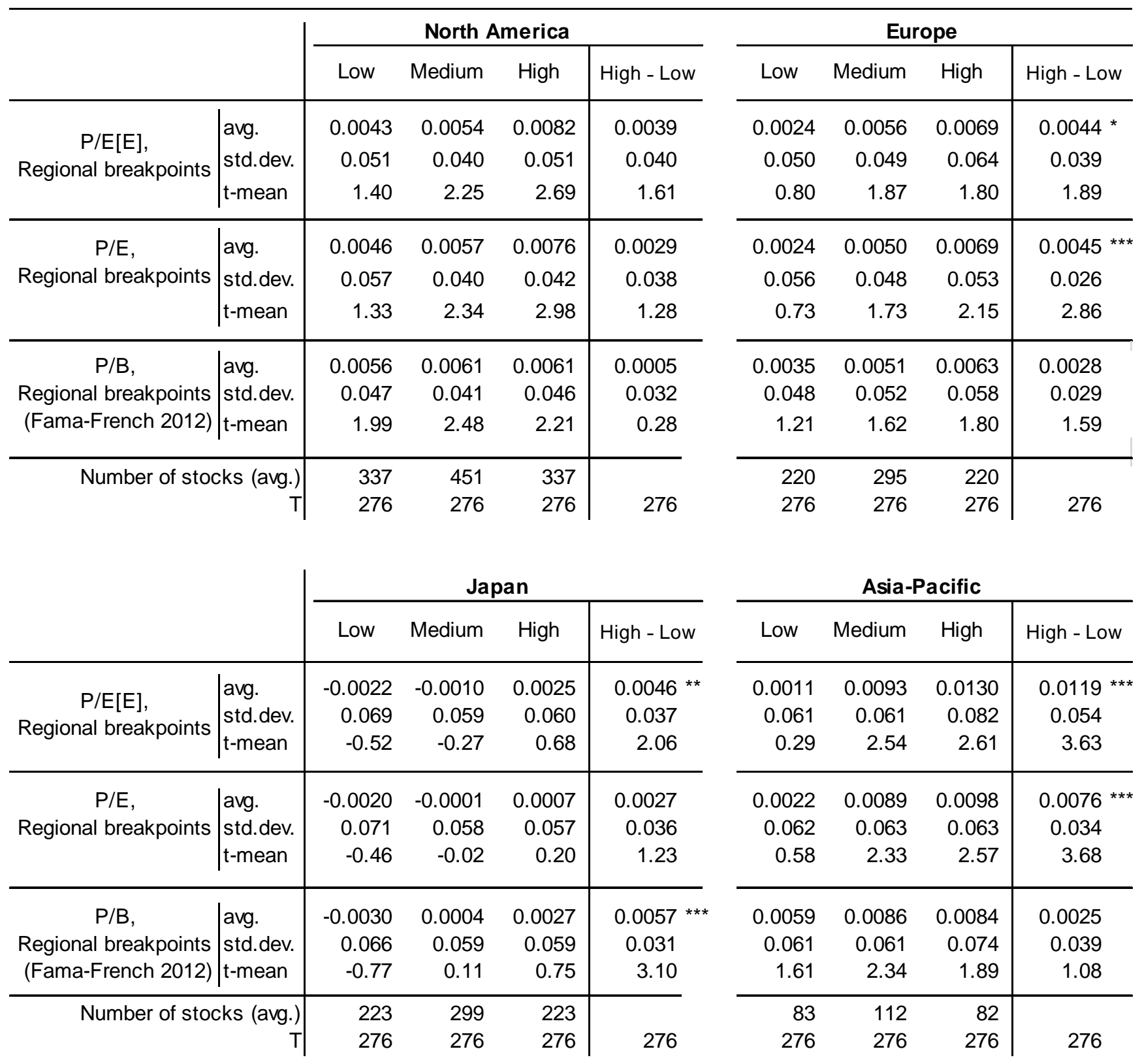


Table 7: Global Fama-MacBeth regressions for the ROE effect

Table 3 contains results of Fama-MacBeth regressions of monthly returns of individual stocks. Stocks are pooled across the globe. The sample has large stocks only. The number of large stocks ( $\mathrm{N}$ in the table) is as of the end of June each year. If historical earnings are positive, $E(+) / P$ is the inverse of the price-earnings ratio. If historical earnings are not positive, $E(+) / P$ is equal to zero and $E / P$ Dummy is equal to 1 . ROE is earnings divided by book value of equity.

Dependent variables are winsorized at the $1 \%$ level in both tails. Panel A has summary statistics. Market cap is in billions of dollars. Panel B has regressions results. Standard errors are corrected for heteroskedasticity and autocorrelation (Newey-West, one lag). The sample period is July 1990-June 2013.

\begin{tabular}{|c|c|c|c|c|c|}
\hline & \multicolumn{5}{|c|}{ Full global sample } \\
\hline & (1) & (2) & (3) & (4) & (5) \\
\hline ROE & $\begin{array}{c}0.0077 \text { ** } \\
(2.59)\end{array}$ & $\begin{array}{c}0.0088 \text { ** } \\
(2.45)\end{array}$ & $\begin{array}{c}0.0075 \text { ** } \\
(2.46)\end{array}$ & $\begin{array}{r}0.0025 \\
(1.29)\end{array}$ & $\begin{array}{r}0.0020 \\
(1.07)\end{array}$ \\
\hline $\ln (B / P)$ & & $\begin{array}{r}0.0013 \\
(1.13)\end{array}$ & $\begin{array}{r}0.0012 \\
(1.12)\end{array}$ & & \\
\hline$E(+) / P$ & & & & $\begin{array}{c}0.0635 \text { *** } \\
(2.68)\end{array}$ & $\begin{array}{c}0.0500 \text { ** } \\
(2.38)\end{array}$ \\
\hline E/P Dummy & & & & $\begin{array}{r}0.0016 \\
(0.71)\end{array}$ & $\begin{array}{r}0.0007 \\
(0.33)\end{array}$ \\
\hline In(Market Cap) & & & $\begin{array}{r}-0.0004 \\
(-1.13)\end{array}$ & & $\begin{array}{r}-0.0004 \\
(-1.19)\end{array}$ \\
\hline $\ln (1+$ Prior Return) & & & $\begin{array}{r}0.0058 \\
(1.42)\end{array}$ & & $\begin{array}{r}0.0055 \\
(1.36)\end{array}$ \\
\hline Intercept & $\begin{array}{c}0.0068 \text { ** } \\
(2.04)\end{array}$ & $\begin{array}{c}0.0081 \text { *** } \\
(2.54)\end{array}$ & $\begin{array}{c}0.0060 \text { ** } \\
(2.04)\end{array}$ & $\begin{array}{r}0.0042 \\
(1.21)\end{array}$ & $\begin{array}{r}0.0030 \\
(0.94)\end{array}$ \\
\hline Average $\mathrm{N}$ & 2752 & 2752 & 2715 & 2752 & 2715 \\
\hline Average $\mathrm{R}^{2}$ & 0.024 & 0.021 & 0.055 & 0.026 & 0.058 \\
\hline $\mathrm{T}$ & 276 & 276 & 276 & 276 & 276 \\
\hline
\end{tabular}


Figure 1: Sample composition

Figure 1 shows number of stocks and the minimum market capitalization of stocks in the sample of large global stocks at the end of June each year. A stock is labeled "large" is it is among the largest stocks cumulatively comprising $90 \%$ of global market capitalization at the end of June. The period is 1990-2012.

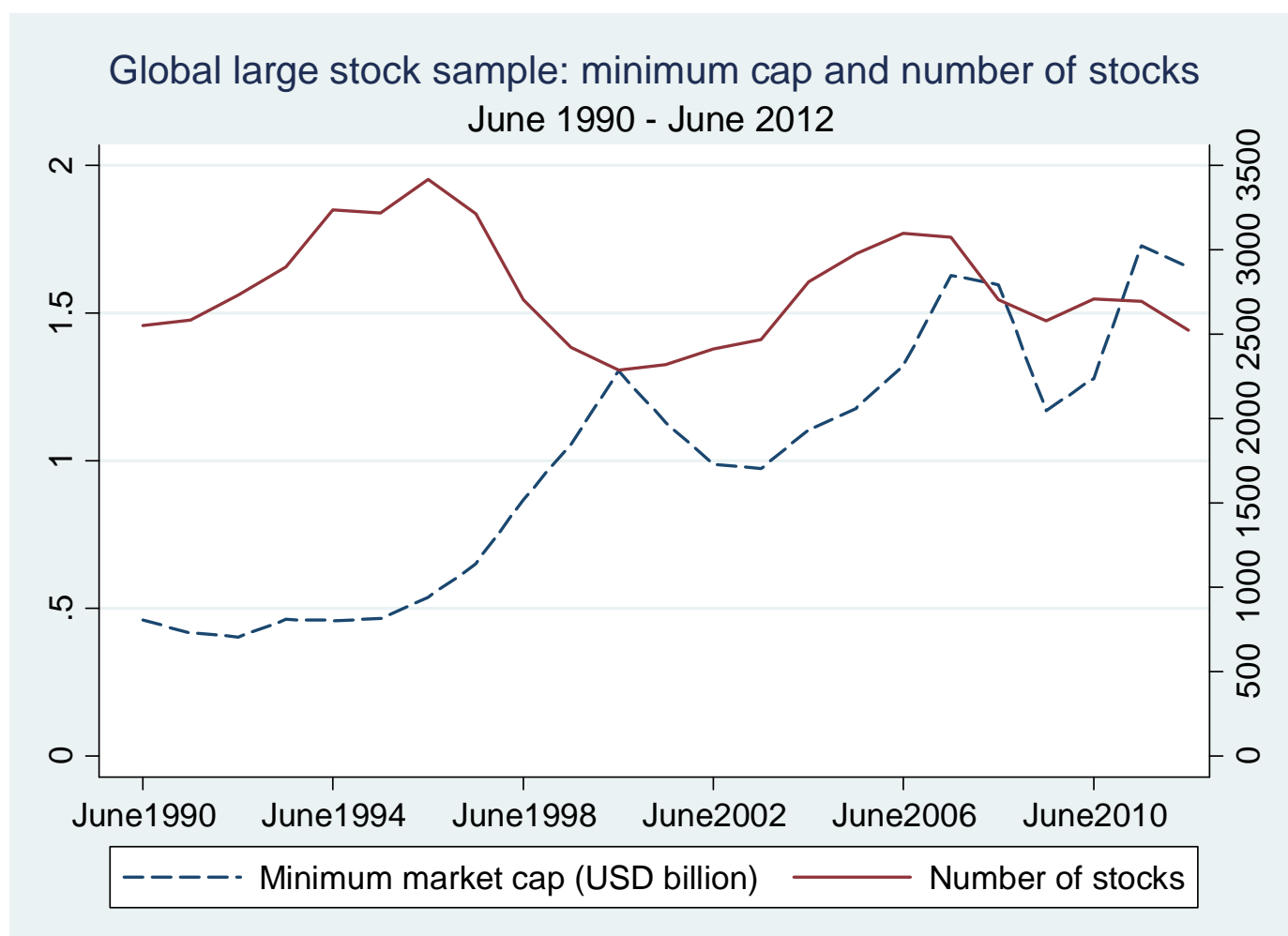




\section{Figure 2: Decile sorts}

Figure 2 shows average monthly World CAPM alphas by valuation ratio deciles. We sort large global stocks into deciles based on $P / E, P / B$, or $P / E[E] . P / E[E]$ is the price-earnings ratio computed using earnings estimates, as described in the text. $P / E$ and $P / E[E]$ portfolios are based on global breakpoints. $P / B$ portfolios are based on regional breakpoints, as in Fama and French (2012). We form value-weighted portfolios within each decile. P/E and P/B portfolios are rebalanced annually, at the end of June each year. P/E[E] portfolios are rebalanced monthly. Excess returns are dollar-denominated, and defined in excess of the 1-month Tbill. The period is July 1990-June 2013.

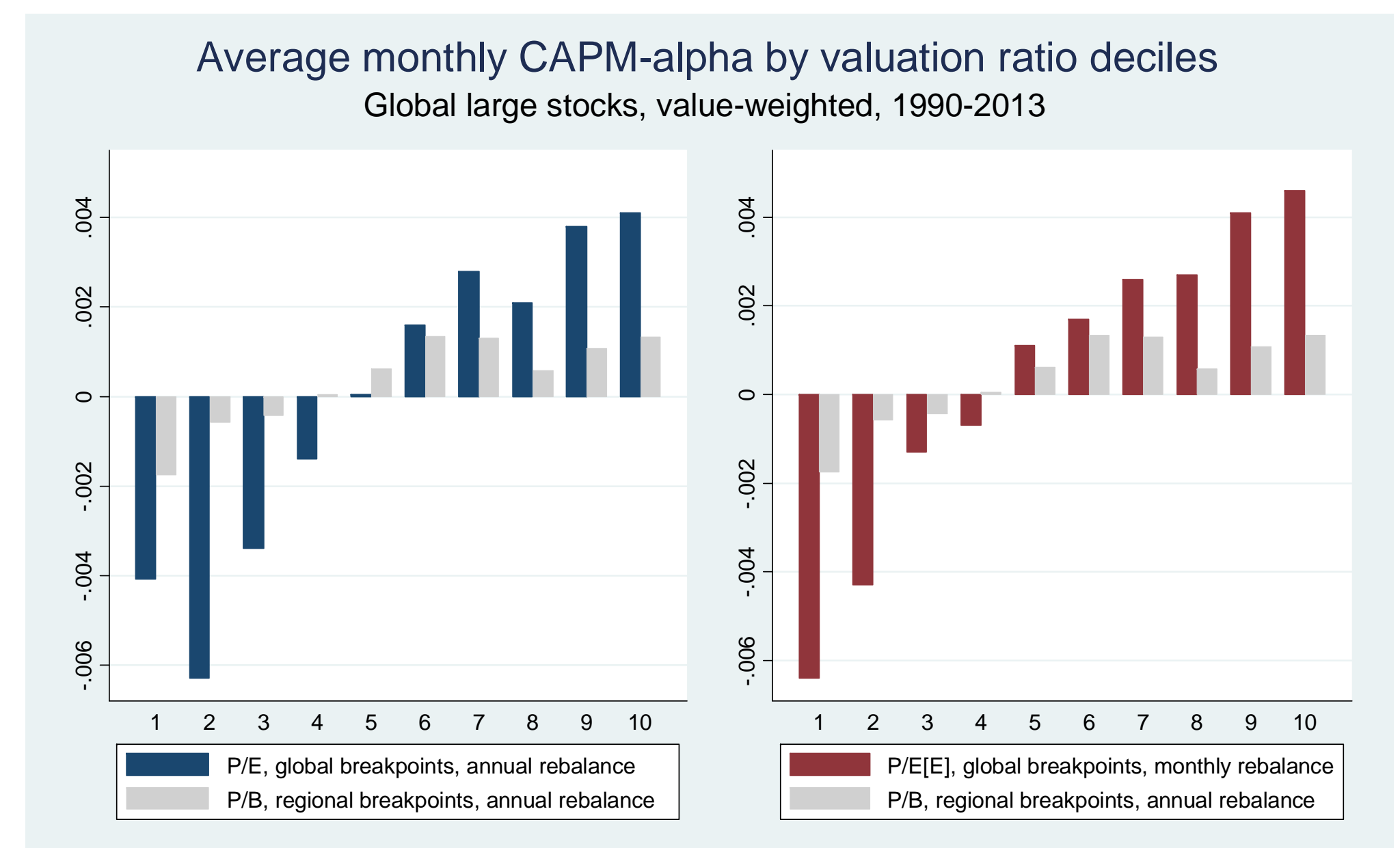




\section{Figure A-1: Comparing samples}

Figure A-1 shows total market capitalization over time for four world regions, including both large and non-large stocks. There are three samples: this paper's sample, Fama and French's (2012) sample, and Asness and Frazzini (2013) sample. Data for plotting the former two are obtained from Ken French's and Andrea Frazzini's webpages respectively. By definition, the market cap of large stocks equals $90 \%$ of the total market cap in each region as of the end of June each year. The period is January 1990 to June 2013.

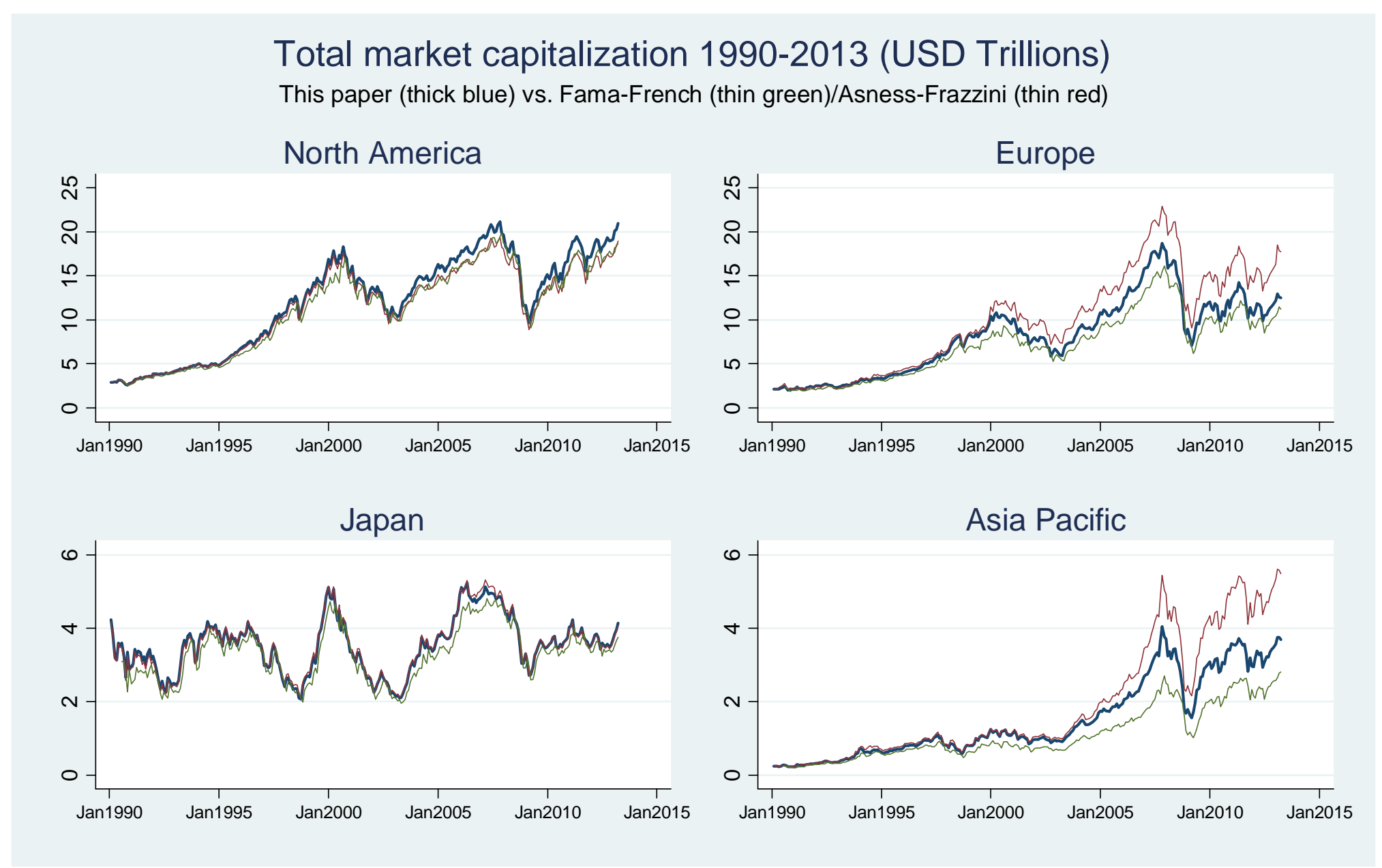




\section{Figure A-2: Minimum market cap of regional sample}

Figure A-2 shows the minimum market capitalization of stocks in each of the four regional samples at the end of June each year. A stock is labeled "large", and thus makes into the sample, if it is among the largest stocks cumulatively comprising $90 \%$ of each region's market capitalization at the end of June. The period is 1990-2012.

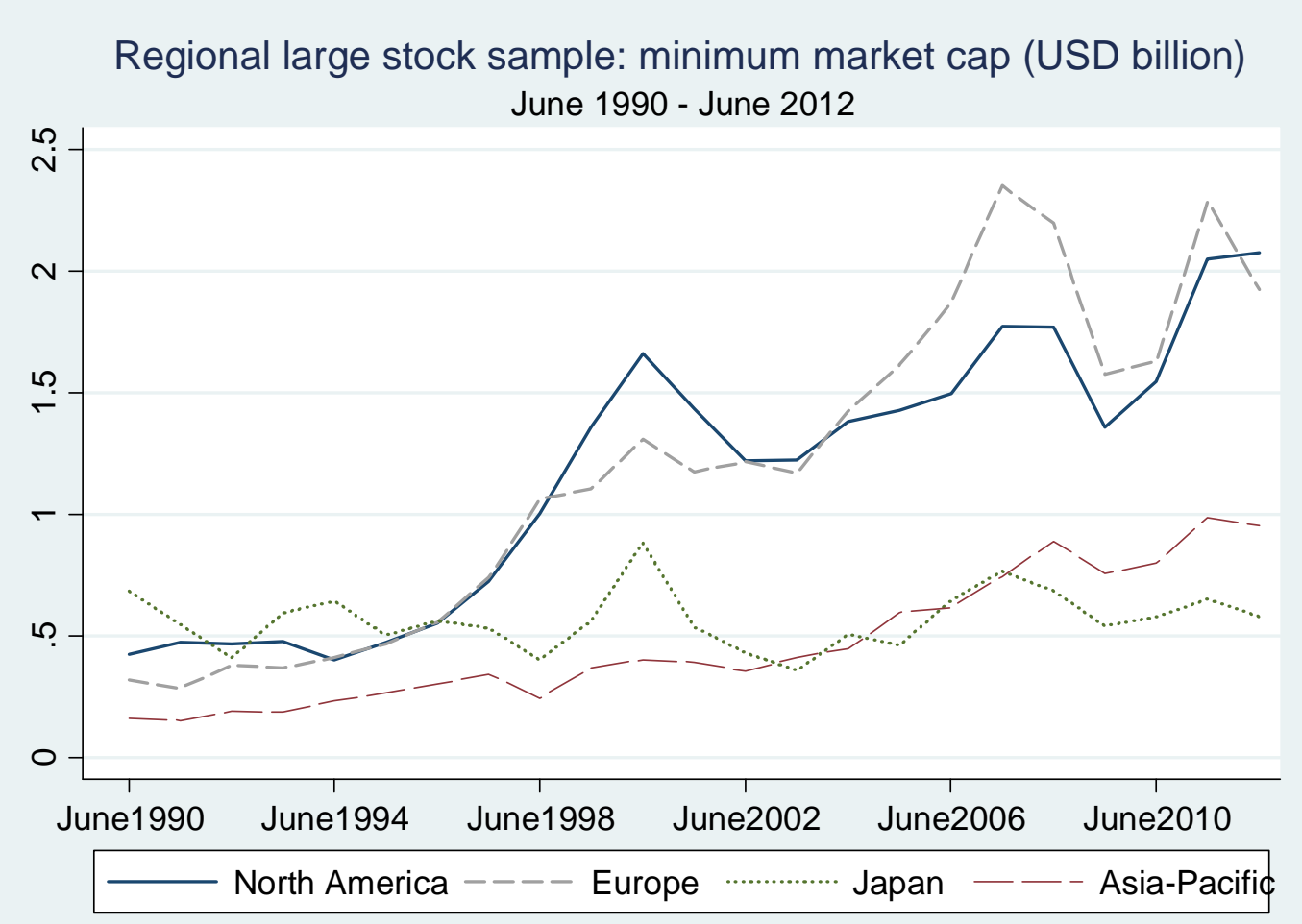

